IJLM

32,2

510

Received 5 December 2019 Revised 16 June 2020 Accepted 27 September 2020

\section{Supply chain management for circular economy: conceptual framework and research agenda}

\author{
Benjamin T. Hazen \\ Logistikum, University of Applied Sciences Upper Austria - Campus Steyr, \\ Steyr, Austria \\ Ivan Russo and Ilenia Confente \\ Department of Business Administration, Universita degli Studi di Verona, \\ Verona, Italy, and \\ Daniel Pellathy \\ Grand Valley State University - Robert CPew Grand Rapids Campus, Grand Rapids, \\ Michigan, USA
}

\begin{abstract}
Purpose - Circular economy (CE) initiatives are taking hold across both developed and developing nations. Central to these initiatives is the reconfiguration of core supply chain management (SCM) processes that underlie current production and consumption patterns. This conceptual article provides a detailed discussion of how supply chain processes can support the successful implementation of CE. The article highlights areas of convergence in hopes of sparking collaboration among scholars and practitioners in SCM, CE, and related fields.
\end{abstract}

Design/methodology/approach - This article adopts a theory extension approach to conceptual development that uses CE as a "method" for exploring core processes within the domain of SCM. The article offers a discussion of the ways in which the five principles of CE (closing, slowing, intensifying, narrowing, dematerialising loops) intersect with eight core SCM processes (customer relationship management, supplier relationship management, customer service management, demand management, order fulfilment, manufacturing flow management, product development and commercialization, returns management).

Findings - This article identifies specific ways in which core SCM processes can support the transition from traditional linear approaches to production and consumption to a more circular approach. This paper results in

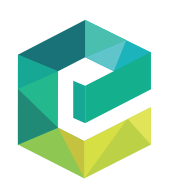

The International Journal of Logistics Management Vol. 32 No. 2, 2021 pp. $510-537$ Emerald Publishing Limited $0957-4093$

DOI 10.1108/IJLM-12-2019-0332 $\overline{\text { C) Benjamin T. Hazen, Ivan Russo, Ilenia Confente and Daniel Pellathy. Published by Emerald Publishing }}$ Limited. This article is published under the Creative Commons Attribution (CC BY 4.0) licence. Anyone may reproduce, distribute, translate and create derivative works of this article (for both commercial and non-commercial purposes), subject to full attribution to the original publication and authors. The full terms of this licence may be seen at http://creativecommons.org/licences/by/4.0/legalcode.

Erratum: It has come to the attention of the publisher that the article, Hazen, B.T., Russo, I., Confente, I. and Pellathy, D. (2020), "Supply chain management for circular economy: conceptual framework and research agenda", published in The International Journal of Logistics Management, Vol. ahead-of-print No. ahead-of-print. https://doi.org/10.1108/IJLM-12-2019-0332, contained a number of errors.

These were:

The placement of all figures at the end of the paper;

The inclusion of a further reading section;

An error in figure 4 that was due to misplaced arrows that disrupted the reading of the flowchart;

The inclusion of a reference to Zhu et al., 2018 in the 'concluding remarks' section.

The errors were either introduced during the editorial process or by the authors, but were not corrected prior to publication due to a production error. All errors have now been corrected in the online version. The figures now feature in the respective sections in the body of the article, the further reading section has been removed, figure 4 has now been corrected to show the correct workflow and the reference Zhu et al., 2018 has now been changed to Liu et al., 2018.

The publisher sincerely apologises for the errors and for any inconvenience caused. 
a conceptual framework and research agenda for researchers and practitioners working to adapt current supply chain processes to support the implementation of $\mathrm{CE}$.

Originality/value - This article highlights key areas of convergence among scholars and practitioners through a systematic extension of CE principles into the domain of SCM. In so doing, the paper lays out a potential agenda for collaboration among these groups.

Keywords China, Sustainability

Paper type Conceptual paper
Supply chain management for circular economy

\section{Introduction}

Human activity is pushing Earth towards a series of "tipping points", with the potential to trigger dramatic changes in the environmental conditions that support modern society (Barnosky et al., 2012; Heikkurinen, 2018). Climate change, widespread land degradation and precipitous loss of biodiversity are all currently observable effects of human activity that have the potential to destabilize the very ecosystems that support human development and sustainment. As Sir Robert Watson, chair of the Intergovernmental Science-Policy Platform on Biodiversity and Ecosystem Services (IPBES), recently reported: "The health of ecosystems on which we and all other species depend is deteriorating more rapidly than ever. We are eroding the very foundations of our economies, livelihoods, food security, health and quality of life worldwide" (IPBES, 2018). Pulling back from these tipping points requires new models of social and economic organization that better align Earth's service capacity with the needs of human populations (Steffen et al., 2015).

The concept of circular economy (CE) represents one of the most promising approaches to organizing sustainable economic activity for the future. CE refers to "a regenerative system in which resource input and waste, emission, and energy leakage are minimised by slowing, closing, and narrowing material and energy loops" (Geissdoerfer et al., 2017, p. 776). Although not new, $\mathrm{CE}$ has recently emerged on the global stage as a potential organizing principle around which multiple economic, political and social stakeholders can rally in their effort to pull the Earth back from the brink of environmental catastrophe (Pearce and Turner, 1990; Andersen, 2007; Ghisellini et al., 2016; Su et al., 2013). Although challenges have been identified (Geissdoerfer et al., 2017), the rewards of implementing CE are notable. The European Commission (2020) estimates that a shift to a functioning CE would grow Europe's GDP by almost $0.5 \%$ by 2030 and the net increase in jobs will be approximately 700,000 compared to actual baseline case and a GDP increase of as much as $7 \%$ relative to the current development scenario.

Yet despite the growing prominence of $\mathrm{CE}$, the concept has garnered relatively little attention in the supply chain management (SCM) literature (Tjahjono and Ripanti, 2019). This absence of CE-related research is striking, given that efficient management of global supply chains is critical to advancing CE. Indeed, a World Economic Forum (2014) report titled "Toward the Circular Economy: Accelerating The Scale-Up Across Global Supply Chains" argues that supply chains are the key unit of action with regard to CE implementation and success, and will be the foundation for driving needed change. As the bedrock of the world economy, supply chain processes arguably require the greatest, and most immediate attention (Ying and Li-jun, 2012, Govindan and Hasanagic, 2018; Min et al., 2019). Thus, a robust framework for planning and managing a CE supply chain is needed (Tjahjono and Ripanti, 2019).

This paper seeks to develop a conceptual understanding of SCM's role in CE, with the aim of providing a framework and research agenda for stakeholders and scholars working to adapt current supply chain processes to support the implementation of $\mathrm{CE}$. Through a systematic process of theoretical extension-which adopts CE as its overarching "method" for exploring processes within the theoretical domain of SCM-the paper maps the intersections between CE principles and SCM processes (Lukka and Vinnari, 2014; Jaakkola, 2020). 
IJLM 32,2

The paper suggests a number of new areas for SCM theory, research, and practice and provides direction for cross-disciplinary, multidisciplinary, and interdisciplinary study.

The paper begins by positioning CE in relation to a number of extant SCM topics including green, sustainable and responsible SCM. The paper then adopts the Global Supply Chain Forum model of SCM (Lambert, 2014) as the basis for systematically relating core supply chain processes to CE. Finally, the paper presents a series of research proposals meant to encourage SCM researchers to explore this highly relevant and impactful topic.

\section{Background: positioning $\mathrm{CE}$ in the SCM literature}

$\mathrm{CE}$ aims to decouple economic activity from the consumption of finite resources, such as carbon-based energy sources, by designing out waste and pollution, keeping products and materials in use and regenerating natural systems. In this way, CE seeks to repurpose economic activity towards creating positive society-wide benefits (Ellen MacArthur Foundation, 2015).

$\mathrm{CE}$ implies the reengineering of many aspects of production and consumption. On the production side, this would include investment in long-lasting product design, with processes that support maintenance, repair, reuse, remanufacturing, refurbishing and recycling (Geissdoerfer et al., 2017, p. 759). Transitioning current production patterns to a functioning CE requires overcoming technological, financial and institutional barriers (Mathews and Tan, 2011; Russo et al., 2019a, b). These challenges are faced by supply chain managers on an almost daily basis, although in ways that are not always systematic, consistent or motivated specifically by a CE orientation.

The supply chain literature suggests applications of various aspects of $\mathrm{CE}$ thinking, particularly in the areas of green supply chain management (GSCM), sustainable supply chain management (SSCM) and closed-loop supply chain management (CLSCM) (Govindan and Soleimani, 2017; Guide and Van Wassenhove, 2009; Stindt et al., 2016; Liu et al., 2018). However, application of $\mathrm{CE}$ thinking in these different areas remains fragmented (Geissdoerfer et al., 2018). Moreover, GSCM, SSCM and CLSCM themselves pursue separate and sometimes competing goals, causing conceptual and practical confusion with regard to their application (Mollenkopf et al., 2010). CE, by contrast, offers a coherent set of five organizing principles for researchers and practitioners (Geissdoerfer $e t$ al., 2017). The systematic application of these principles can draw on insights from GSCM, SSCM and CLSCM, while at the same time overcoming differences in these areas.

The aims of GSCM, SSCM, and CLSCM differ from each other and from CE. GSCM focuses exclusively on integrating environmental thinking into SCM activities, with the aim of converting traditional SCM activities into a newly updated set of "green" activities (e.g. green purchasing, green manufacturing, green logistics) that limit a supply chain's environmental impact (Hernani et al., 2005; Srivastava, 2007; Hazen et al., 2011; Sarkis et al., 2011). SSCM focuses instead on the broader notion of organizational performance by integrating social and environmental metrics into SCM processes as a means of improving a company's long-term outcomes (Kirchhoff et al., 2016; Carter and Rogers, 2008; Searing and Müller, 2008). Finally, CLSCM focuses on the return, disposition, and value recapture of post-sale products (Guide and Van Wassenhove, 2009). Although each of these approaches provide important insights, they lack a coherent set of organizing principles that can overcome their differences.

Adopting a CE perspective-with its five principles of closing, slowing, intensifying, narrowing and dematerializing material and energy loops, as defined in Table 1 - might allow researchers and managers to incorporate insights from GSCM, SSCM and CLSCM within a systematic framework that can help guide the rethinking of current modes of economic activity. For instance, CLSCM principles clearly describe fundamental tools for achieving the CE objectives of closing and intensifying loops (Habibi et al., 2017; Zeng et al., 2017). Likewise, 
Circular supply chain management loops

Closing loops Defines the practice materials reuse through the recycling, remanufacturing and similar processes Bocken et al. (2016), Geissdoerfer et al. (2018)

Slowing loops Is about prolonged use and reuse of goods over time, through processes such as designing durable goods and product lifecycle extensions Leising et al. (2018)

Intensifying loops

Suggests a more value-intensive use phase of materials or products, such as my promoting pooled or shared product usage vice individual consumption Geissdoerfer et al. (2018)

Narrowing loops Concerns overall resource efficiency, using fewer resources per product Bocken et al. (2016)

Dematerializing Refers to substituting products for services in a way that increases utility and loops longevity of products and materials Geissdoerfer et al. (2018)

Table 1.

Five principles of circular economy

insights from GSCM will be critical as researchers and practitioners seek to narrow loops by reducing resource consumption and improving efficiency associated with production processes (Kazancoglu et al., 2018). Finally, integrating social and environmental metrics into supply chain processes through SSCM represents a critical building block for achieving CE's more holistic goal of repurposing economic activity toward creating positive society-wide benefits. In this way, adopting a CE perspective in SCM would build on previous work in GSCM, SSCM and CLSCM, while providing a coherent set of organizing principles that can overcome their differences.

Structured or systematic literature reviews regarding the intersection between $\mathrm{CE}$ and SCM are scarce. In particular, CE has received little attention in traditional supply chain, logistics, and operations management journals (Liu et al., 2018; Tjahjono and Ripanti, 2019). However, some notable reviews have begun to inform the relationship between SCM and CE.

For instance, Liu et al. (2018) critically analysed theories that can provide insights for, and further link, GSCM and CE. In doing so, they particularly focus on GSCM and CE literature. Taking a broader perspective, de Angelis et al. (2018) were among the first to review the literature on SCM and $\mathrm{CE}$. Their findings reveal not only the lack of literature bridging $\mathrm{CE}$ and SCM, but also the dire need for more practical information regarding how to introduce circular supply chains into existing real-world contexts. Although cases on sector-specific recycling, reverse logistics and closed loop supply chains currently exist (Bernon et al., 2018), there are no large-scale industrial examples of $\mathrm{CE}$ principles being adopted across supply chain processes, further motivating this current paper.

In addition, Tjahjono and Ripanti's (2019) structured literature review suggests 15 core CE values that can be considered when designing a circular, closed-loop supply chain and supporting reverse logistics. However, more work is required to detail how these values will be embedded, suggesting the need for more research on the fundamental processes underlying CE integration with SCM. To this end, Farooque et al. (2019) conducted a structured review of almost 300 articles related to $\mathrm{CE}$ across a variety of disciplines in order to develop an understanding of the body of research related to what they term "circular supply chain management". This important work helps to lay the foundation for this current study in that it elucidates the need fora paradigm shift in the way products, processes, and supply chains are designed and operated for $\mathrm{CE}$ implementation.

Notwithstanding the aforementioned reviews, there remains a lack of detailed understanding in the literature regarding how SCM processes can be leveraged to achieve $\mathrm{CE}$ goals. Developing this understanding is the primary aim of the present paper. To that end, we drill down into a detailed discussion of how the five principles of $\mathrm{CE}$ specifically intersect with core SCM processes. 
IJLM

32,2

514

\section{Approach}

This paper adopted a theory extension approach based on Lukka and Vinnari (2014). A semistructured literature review was conducted as the basis a systematic discussion of core SCM processes in light of CE principles.

\section{Theory extension}

Theory extension is a process of exploring the fundamental principles or concepts of a theory within a new domain to refine understanding of the original theory and/or suggest novel theoretical connections within the new domain (Whetten, 1989, 2009). Lukka and Vinnari (2014) lay out an approach to theory extension based on a distinction between what they call "method" and "domain" theory. "Domain" theory refers to "a particular set of knowledge on a substantive topic area that is situated in a field or domain" (Lukka and Vinnari, 2014, p. 1309). "Method" theory, by contrast, refers to an overarching conceptual system or theoretical lens that is used to studying the substantive issues of the domain. Thus, in the Lukka and Vinnari (2014) approach, the "method" provides the structure (or method) for exploring concepts in the "domain", thereby allowing for theoretical extension.

Applying the Lukka and Vinnari (2014) approach, we adopted a CE perspective (method) to explore substantive concepts in SCM (domain). In particular, we explored each of the eight core supply chain processes identified by the Global Supply Chain Forum framework (Lambert, 2014) - customer relationship management, supplier relationship management, customer service management, demand management, order fulfilment, manufacturing flow management, product development and commercialization, returns management - in light of five $\mathrm{CE}$ principles identified in the literature - closing loops, slowing loops, intensifying loops, narrowing loops, dematerialising loops (Geissdoerfer et al., 2017).

\section{Search strategy}

In order to discover both theoretical and practical discussions of the intersection between $\mathrm{CE}$ and SCM, the research team conducted a semi-structured literature review that covered both the scholarly and practitioner literatures. The search was organized into two phases following the approach suggested by Cerchione and Esposito (2016) and Sashi et al. (2018).

The first phase represented an academic literature search. In this phase the research team reviewed all studies published on CE over a ten-year period (2010-2019) in six of the top supply chain management journals: Journal of Operations Management, Supply Chain Management: An International Journal, Journal of Supply Chain Management, Journal of Business Logistics, International Journal of Physical Distribution and Logistics Management and International Journal of Logistics Management. The goal of this phase was to uncover the most recent academic research on the intersection between $\mathrm{CE}$ and core SCM processes. The research team based its search on terminology found in the Global Supply Chain Form model of SCM (Lambert, 2014). The Global Supply Chain Form model is the most cited model of SCM in the literature and therefore represented an appropriate basis for the academic literature search.

The following combination of terms were used to search article titles, abstracts, and keywords in the selected journals:

(1) "Circular economy" and "customer relationship management"

(2) "Circular economy" and "supplier relationship management"

(3) "Circular economy" and "customer service management"

(4) "Circular economy" and "demand management"

(5) "Circular economy" and "order fulfilment management" 
(6) "Circular economy" and "manufacturing flow management"

(7) "Circular economy" and "product development and commercialization"

(8) "Circular economy" and "returns management"

This academic literature review search yielded only a small number of studies, after coincidental results, results using overlapping terminology, and other unsuitable results were eliminated.

The second phase represented a search of the practitioner literature. This part of the review was, by necessity, less structured. Still, this phase of the search was crucial for identifying valuable questions based on industry observation (Mentzer, 2008), with a focus toward uncovering big ideas with high practical relevance (Frankel et al., 2008; Lambert and Enz, 2015; Stank et al., 2017; Lambert, 2019). The search focused on white papers, reports, practitioner journals, and other reputable practitioner outlets. Numerous practitioners were found during the second phase.

By conducting the literature review in this way, the research team was able to capture information about the intersection between $\mathrm{CE}$ and core supply chain processes at the level of both theoretical generalization (from academic journals) and at the level of practical implementation (from practitioner outlets). The discussion that developed out of the identified literature became the basis for the research team's suggestions for additional research and theoretical conceptualization. In this way, the literature review allowed for theory extension that was context-sensitive and focused the implement of $\mathrm{CE}$ within specific SCM processes (Tranfield et al., 2003). More broadly, the approach adopted here-both in terms of theory extension and literature review -provides an example of how scholars can answer the call to be thought leaders, who are able to identify emerging business challenges and contribute research on big ideas (McKinnon, 2013; Lambert, 2019).

\section{SCM processes from a CE perspective}

In the following discussion, each of the eight core SCM process is introduced and reviewed from a CE perspective, with the aim of identifying opportunities to restructure current supply chain processes to support the implementation of $\mathrm{CE}$ principles of closing, narrowing, slowing, intensifying and dematerializing resource loops.

\section{Customer relationship management for $C E$}

Customer relationship management (CRM) encompasses all of a firm's customer-facing processes, and links customers to the rest of the firm's supply chain processes. CRM includes reviewing corporate and marketing strategies, segmenting customers, and deciding how to differentiate offerings (Lambert, 2014). Decisions in the area of CRM must align vertically with firm-level strategies. Assuming the adoption of a $\mathrm{CE}$ orientation at the firm level, there are numerous was in which CRM processes be restructured to support the implementation of CE principles.

First, marketing strategy may be revised to highlight $\mathrm{CE}$ oriented conduct as a key differentiator in how a company delivers value to customers. Second, CRM processes may be restructured to forge longer-term relationships that position customers as proactive partners in supply chain decision making. Such long-term CRM is in keeping with a CE perspective that views consumers, not as the end of linear supply chain, but as the centre of a dynamic supply network. Finally, CRM processes may be reorganized to enable the eventual recapture of used products or residuals, while at the same time providing services to extend product lifecycles.

Research on closed-loop supply chains provides insight into how the CRM process might be revised for CE. Closed-loop SCM is the design, control, and operation of a system to 
IJLM 32,2

\section{6}

maximize value creation over the entire lifecycle of a product with the dynamic recovery of value from different types and volumes of returns over time (Govindan and Soleimani, 2017; Guide and Van Wassenhove, 2009). The concept of the closed-loop supply chain anticipates many of the issues raised by $\mathrm{CE}$ implementation, with $\mathrm{CE}$ representing a large-scale operationalization of many closed-loop supply chain concepts. Importantly, product returns and customer management concerns are strategic in nature (Thierry et al., 1995) as they necessary relate to how a firm positions itself in a competitive marketplace and, eventually, the CE.

A growing stream of research is also bringing the closed-loop concept to the business-toconsumer arena, considering how to motivate and support end-consumer participation (Abbey et al., 2015; Blackburn et al., 2004). Recent research has highlighted that consumers' needs, perceptions and decisions are becoming relevant parts of efficient and effective SCM processes (Esper and Peinkofer, 2017). For a closed-loop supply chain to be tenable, customers (businesses and end-consumers) need to return products and residuals to the supply chain, but also need to be willing to use products that are both designed for reusing/ remanufacturing/recycling till the new generation of bio-based products, and also derived from such processes (Abbey et al., 2015; Reinders et al., 2017; Wang and Hazen, 2016). Without broader acceptance of reusing/remanufacturing/recycling, customers will act as barriers to $\mathrm{CE}$, no matter how well the operational system is designed. Thus, new strategies are required for introducing sustainable practices to customers (Prieto-Sandoval et al., 2018). For example, remanufacturing seems to have some limitation, as only few consumers perceive remanufactured goods to be as good as new ones, which presents a major barrier to more widespread adoption (Hazen et al., 2017).

Customer acceptance of products produced using CE processes is currently seen as one of the principal barriers that is preventing expansion of closed-loop networks (Liang, 2011). Research on consumer acceptance of these products is emerging, and many problems have been identified.

For instance, remanufacturing is the cornerstone of closed-loop supply chains, and denotes the process through which used items are brought to like-new condition via cleaning, repairing, inspecting and rebuilding components (Hazen et al., 2012). Unfortunately, consumers typically believe that remanufactured products are unattractive, although brand equity and price discounts can help to overcome some negative perceptions (Abbey et al., 2015). Such behaviour is specified by waste reduction within a closed loop supply chain (Cole et al., 2017). Further, research aimed at promoting adoption has shown that educating consumers and demonstrating value helps to allay consumer concerns (Wang and Hazen, 2016). Convincing consumers to switch towards products derived from closed-loop processes will be instrumental toward promoting $\mathrm{CE}$ and represents a key area for $\mathrm{SCM} / \mathrm{CE}$ collaboration. As an example, in November 2016 Apple began selling officially certified reconditioned iPhones through its online store in the US for the first time. The choice of the direct channel can be justified by the need to inform the customer about the validity and quality of the product (Benjamin, 2016).

Although some headway is being made with regard to identifying and employing mechanisms to promote consumer acceptance of CE-derived products, less research is devoted towards how to incentivize other customer-facing activities needed for $\mathrm{CE}$. These roles include returning products and residuals to appropriate collection points, limiting disposal of products (especially those that retain some residual value), and using products in a fashion that extends product lifecycle. Indeed, consumer behaviours will need to dramatically change in order for $\mathrm{CE}$ to be tenable. Research is needed on consumer education (i.e. informing consumers on their role in $\mathrm{CE}$ ), regulatory intervention (i.e. penalties associated with refuse, or incentives associated with compliance with $\mathrm{CE}$ initiatives), and increasing ease of participation in $\mathrm{CE}$ (i.e. optimization and convenience of collection points plus incentives 


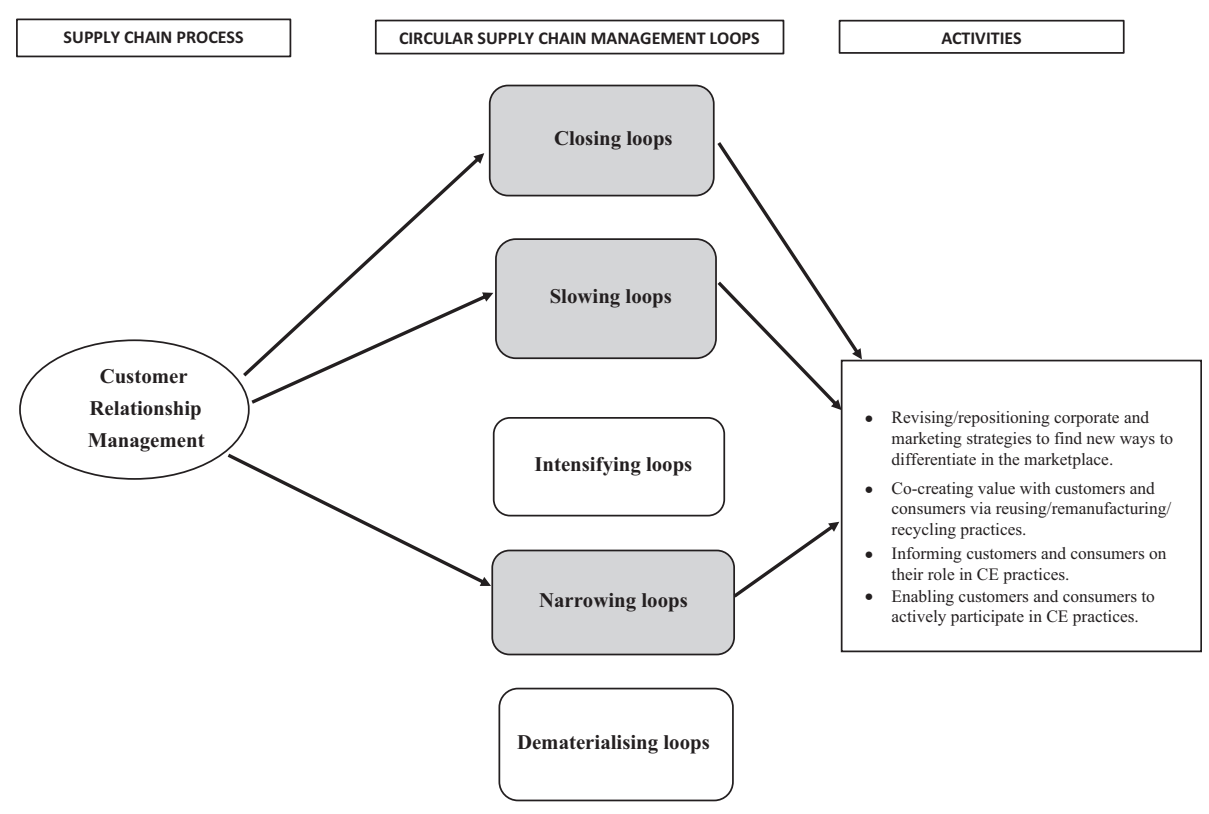

Supply chain management for circular economy

provided for returning products). For instance, H\&M's garment collecting initiative gathered more than 20,000 tonnes of garments in 2018, giving new life to the equivalent of 103 million $T$-shirts. Thanks to this initiative, any clothes or home textiles that are no longer wanted or needed can be dropped off at any local H\&M store and given new purpose (H\&M, 2019) (see Figure 1).

\section{Supplier relationship management for $C E$}

Along with down-stream relationships, up-stream supplier relationships provide key linkages through which other supply chain processes are employed and are recognized as important antecedents to many aspects of performance (Carr and Pearson, 1999). The nature of supplier relationships has changed over the past several years such that buyers often seek to establish strategic partnerships with suppliers in lieu of keeping suppliers at arm's distance (Monczka et al., 1998). This trend is encouraging for $\mathrm{CE}$, where firms will be required to collaborate closely with all supply chain partners. Indeed, supply chain cooperation and careful supplier selection practices taking into consideration environmental performance is shown to lead to achievement of $\mathrm{CE}$ objectives and can even evoke performance at the firmlevel (Zhu et al., 2011; Petljak et al., 2018). However, the idea of supplier segmentation and preferred suppliers might need to change, in that the $\mathrm{CE}$ will necessarily drive firms to collaborate only with strategically aligned supply partners. This will lead to sharpened supplier selection criteria based on suppliers' environmental conduct and on suppliers' location in order to "narrow the loop" (Geissdoerfer et al., 2018).

As a consequence, work is needed to encourage the close supplier relationships necessary for $\mathrm{CE}$ success. These relationships will no longer be based solely on economic considerations, but environmental considerations as well. This can help firms better understand how to stimulate their suppliers to adopt their proposed CE project. For instance, IKEA has developed and implemented their "IKEA Way" for purchasing products, materials and services, which functions as a Supplier Code of Conduct. It comprises IKEA's minimum 


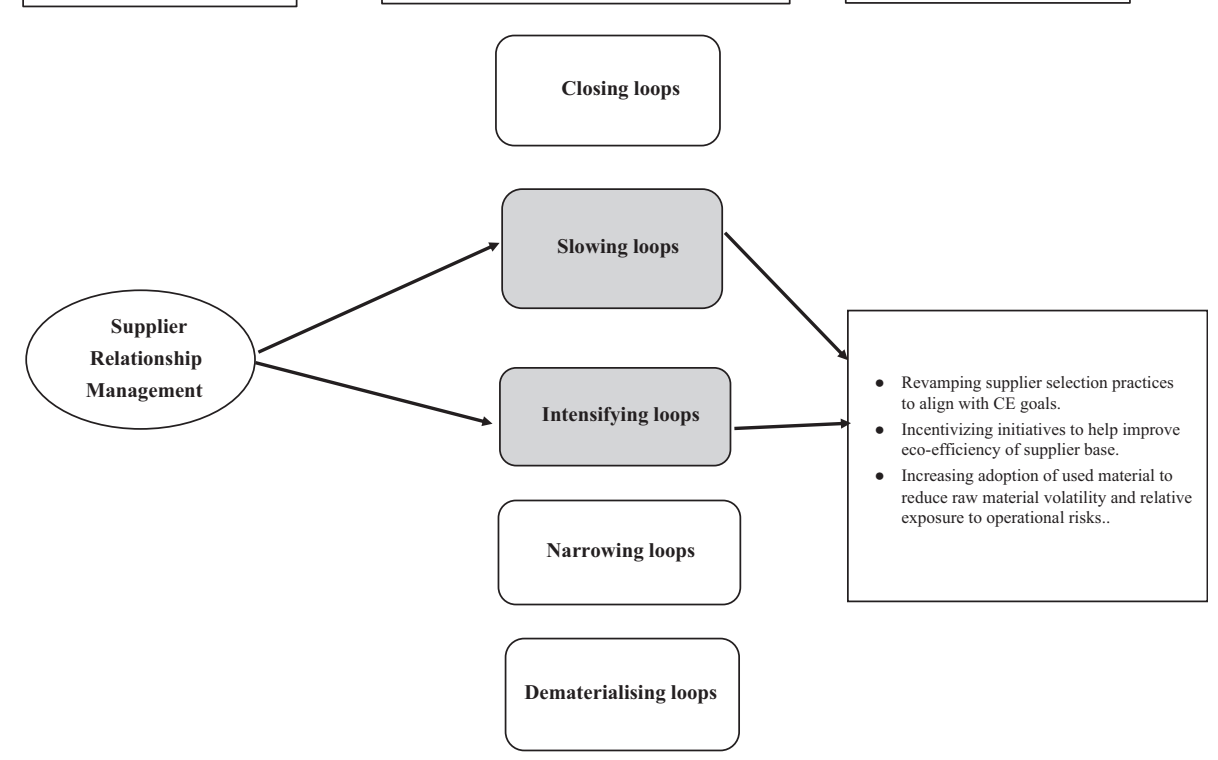

Figure 2.

SRM process interface with circular supply chain loops and the relative activities

\section{8}

requirements relating to environmental, social and working conditions (including child labour restrictions) that will allow the company to work more closely with suppliers in order to develop further CE-related initiatives (IKEA, 2016).

Two criteria have been proposed to promote and examine such collaborative eco-industrial initiatives related to $\mathrm{CE}$. Initiatives should improve the eco-efficiency of the group of firms (supply chain) as a whole while also improving the profit position of at least one firm without damaging the position of others (Mathews and Tan, 2011). Ideally, CE initiatives improve lean management, eco-efficiency and profit position of multiple (if not all) firms (Martínez-Jurado and Moyano-Fuentes, 2014; Mollenkopf et al., 2010). However, realizing both criteria has proved difficult in most supply chains, where supply chain optimization is often subordinated to the firm level through initiatives such as lean, just-intime delivery, and others. Finally, a circular approach causes reduced volatility and might improve security of supply. Because of a lower need of virgin materials linked with an increase need of used material and collaboration with both suppliers and customers, the exposure to supply chain disruptions related to natural disasters, geopolitical imbalances or unsafe relations is decreased (see Figure 2).

\section{Customer service management for $C E$}

The supply chain's role in CE no longer ends at the point of sale, but after-sales support requirements will need to consider all phases of a product's life-cycle. Similar to new requirements for customer relationship management, the idea of customer service needs to be reconceptualized. Most notably, a servitization or service-dominant logic approach where products are offered in the form of services will need to be adopted on a wider scale (Edvardsson et al., 2011). Such services range from repair to periodical maintenance of products with the goal of extending the useful life of products being used to perform services.

Literature on servitization generally describes means through which manufacturers integrate services with their product offerings (Neely, 2009). However, "complete" 
servitization of many products will be required to fully implement $\mathrm{CE}$ principles. This means, for example, that those in the automobile industry might no longer characterize their businesses in terms of manufacturing and delivering automobiles to consumers, but they will need to think of themselves as purveyors of transportation services. Arguably, automobiles will not need to be personally owned, but rather those in need of transportation will summon a provider on an as-needed basis. Evidence of such a transition can be found in the strategic partnership between General Motors and Lyft (General Motors, 2016). As part of this agreement, General Motors promised to populate Lyft rental hubs with GM vehicles, where Lyft drivers can rent them short-term on an as-needed basis. This means that vehicles can essentially be utilized around the clock by different drivers, increasing both economic and environmental efficiencies gained via collaborative consumption. This approach will promote optimal utilization of durable goods and enable closed-loop supply chain practices to standardize management of fleet assets. Rental, leasing, and reuse are typical examples of CE implementations that help to create a stable and long-term relation between the customer and the supplier. For instance, IKEA announced two important initiatives to help support CE via developing a furniture exchange system and testing furniture and kitchen-item rentals (Hirsh, 2019; World Economic Forum, 2019).

In sum, literature on supply chain structural changes in support of traditional servitization approaches is limited, although there is some evidence to support that changes can be tenable ( $\mathrm{Ng}$ et al., 2012). This change has generated increasing importance of end-consumers and recently with the advent of e-shopper marketing there is incremental need of measuring and controlling SCM performance (i.e. delivery options, flexibility, reverse logistics) from downstream in order to provide valuable insights regarding a company's supply chain strategy (Esper and Peinkofer, 2017; Stolze et al., 2016). Complete servitization and service-dominant logic strategies that enable value co-creation across the supply chain (to include consumers) will require significant supply chain restructure, and is an area where collaboration between CE and SCM scholars is needed (see Figure 3).

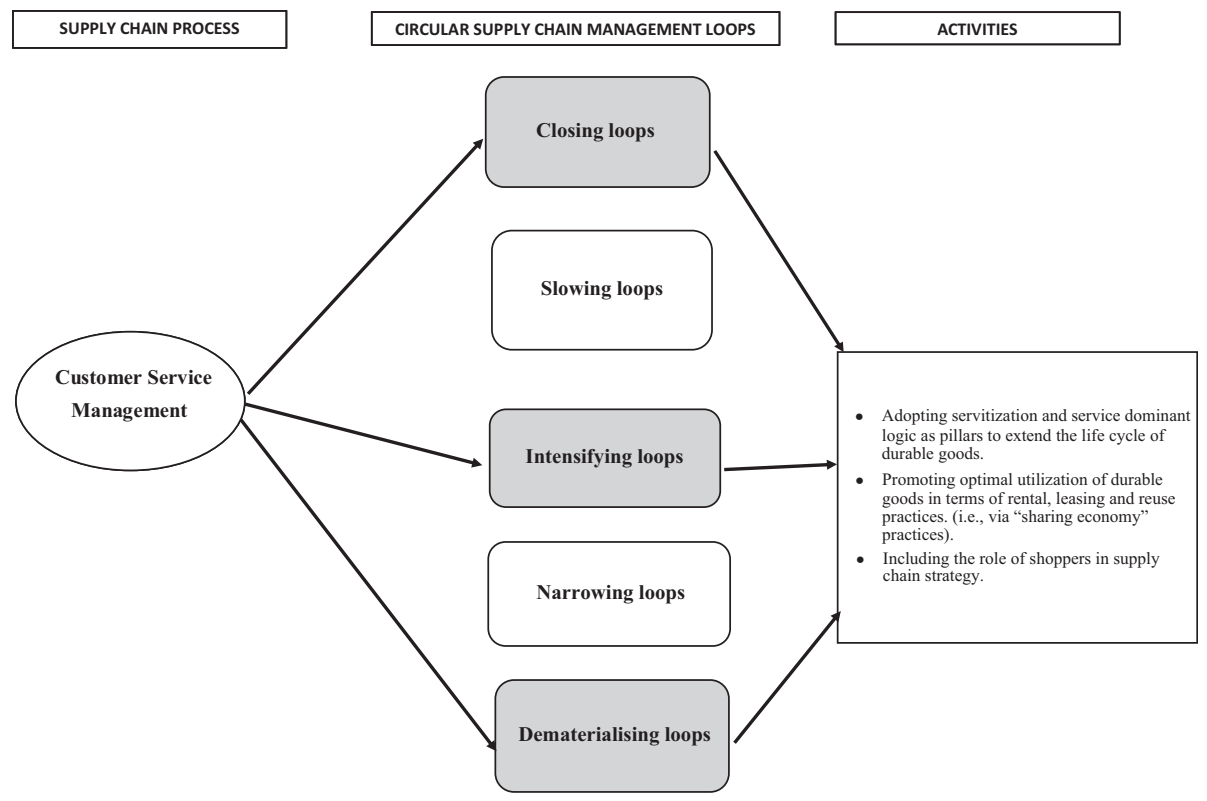

Supply chain management for circular economy
Figure 3.

CSM process interface with circular supply chain loops and the relative activities 


\section{IJLM}

32,2

520

\section{Demand management for $C E$}

Demand management entails forecasting, planning for, and managing demand for products and services (Croxton, 2003). Demand forecasting encompasses sales forecasting, but takes a broader, enterprise view of how demand affects all components of the supply chain. Indeed, some scholars suggest a refocus from "supply" chain considerations to "demand" chain considerations (Christopher and Ryals, 2014). This perspective leads to think about how to join forecasting and planning practices, and their impact on forecasting accuracy and costs. This means to remodel supply chains into demand chains creating the possibility that waste and obsolescence can be reduced. This will force companies to not create demand unless they can supply.

Considering the regenerative nature of $\mathrm{CE}$, demand and consumption patterns will dramatically change. This will indeed be disruptive to extant demand management practices and is one of the areas in greatest need of collaboration across the CE and SCM communities. Not only must simple demand for disposable products decline for CE success, but changing (and unknown) demand patterns reflected by reuse, reduction, and recycling practices will significantly alter extant forecasting and planning models.

Mathews and Tan (2011) suggest that CE initiatives are conducted at three levels. Some initiatives reside at a single enterprise or are confined to a small group of enterprises, enhancing energy and resource efficiency. At the second level are initiatives residing at a supply chain-level, whereby a larger group of firms share certain streams of resources to enhance collective efficiency. The third level, which is currently found mainly in China due to its proactive and publicized approach to implementing CE, involves a whole municipal area. At this level, recapturing and regenerating resources via interconnected processes is promoted through economic and administrative incentives; conversely, failures are penalized in some way. Demand management will therefore require acquiescence to this third, higherorder approach.

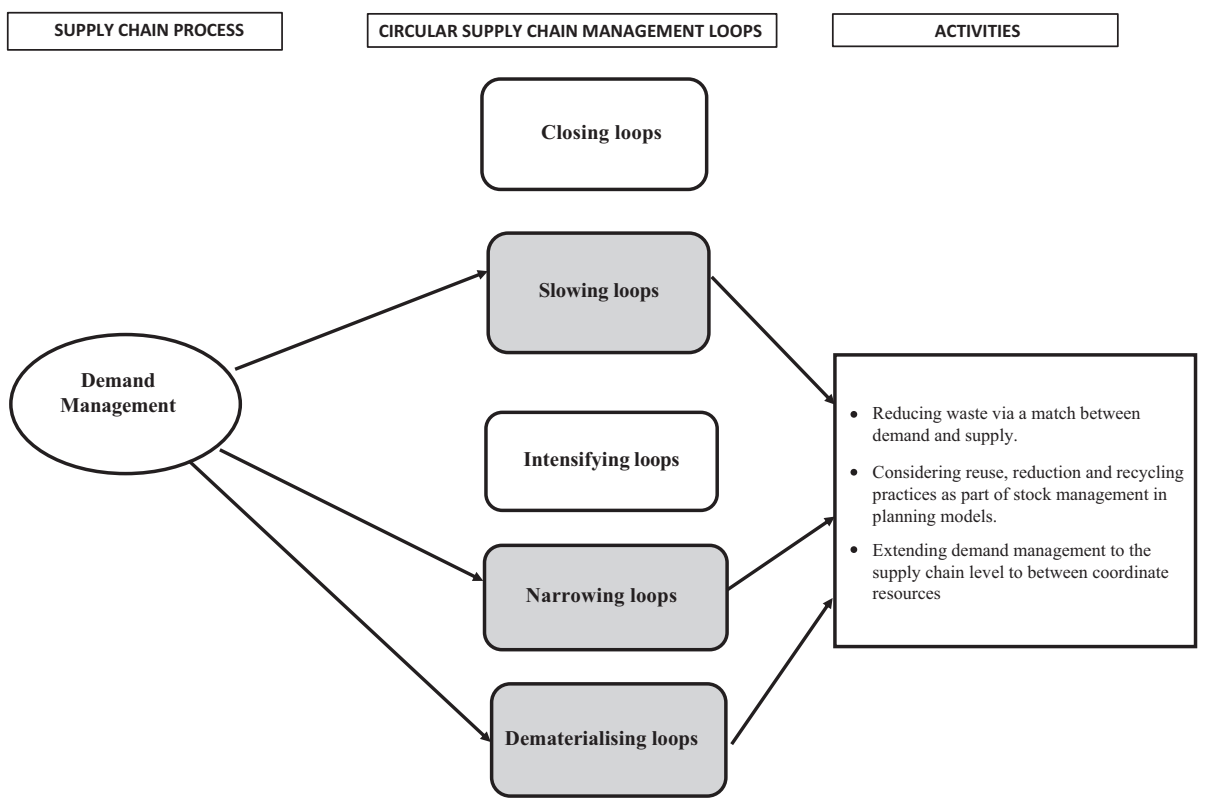

Figure 4.

DM process interface with circular supply chain loops and the relative activities 
Research can examine this level from a common pool resource management perspective, which provides an alternative to Hardin (1968) tragedy of the commons theory to suggest that common pool resources can be collectively managed to ensure all participants use resources according to the community's rules, optimizing for community vice local benefit (Ostrom et al., 1999). Demand management typically seeks to optimize focal-firm performance and common pool resources are often not optimally used across the supply chain. Advances in supply chain demand management have encouraged demand management on a supply chain level (Lambert and Cooper, 2000). The problem of coordinating resources to manage demand requires further investigation, and is one area where $\mathrm{SCM}$ and $\mathrm{CE}$ scholars can collaborate to find solutions (see Figure 4).

\section{Order fulfilment for $C E$}

Order fulfilment refers to the processes concerned with receiving, processing and delivering orders (Croxton, 2003). Processes regarding receiving and processing orders have changed substantially over the past several years, evolving from orders received via phone, fax or mail, to orders received via electronic data interchange, e-commerce and completely automated processes. These advancements will be the bedrock of $\mathrm{CE}$ order fulfilment practices, and industry leaders such as are already introducing disruptive innovations that will change the fulfilment landscape in a manner that can eventually sustain CE. For instance, Amazon's Prime Now initiative enables one-hour delivery of thousands of products in select markets (Amazon Prime Now, 2015). This initiative requires revamping the entire fulfilment process, moving distribution facilities from suburban outposts to city centres, and adopting urban transportation delivery modes (i.e. bicycle couriers, public transportation networks and potentially drone aircraft) to make fast and efficient deliveries. Pooling products closer to consumers and using existing and more sustainable transportation will be a key component of $\mathrm{CE}$, and research advancing the operationalization of these concepts is needed.

Green logistics is arguably the longest-running research stream in the sustainable SCM space, and is a primary mechanism for achieving today's CE objectives (Zheng and Zhang, 2010). Green logistics is motivated by environmental benefits, but is typically implemented as part of a cost-savings initiative (Murphy et al., 1996; Rao and Holt, 2005). The lessons learned over the past two decades of research suggest that marrying cost savings to environmental benefits is paramount to organizational adoption. Indeed, it is intuitively obvious that for $\mathrm{CE}$ to be successful, bottom lines will have to remain stable or, ideally, be enhanced. To this end, green logistics literature has typically focused on these win-win solutions such as adoption of more efficient vehicles (air, ground, and water vessels), use of more efficient transportation modes, improved vehicle utilization, optimized routing networks, alternative packaging and warehousing approaches, and use of alternative energies to support logistics (Alstone et al., 2014; McKinnon et al., 2010). Moreover, logistics service providers have to operate in urban areas where they encounter several external problems and environmental pressures to serve the last mile (Castillo et al., 2018). Continued urbanization and overall demographic growth is projected to add 2.5 billion people more to the urban population by 2050 , bringing the proportion of people living in cities to $66 \%$. This trend will force municipality to accelerate the transition from linear economy to circular economy in managing differently the urban logistics of goods, means and people.

Although these topics have been well developed in the literature, further advancements in consideration of $\mathrm{CE}$ are required. For instance, more environmentally efficient practices will need to be replaced with zero-impact practices. In addition, as noted with the Amazon Prime Now example, logistics networks need not merely be improved, but restructured. Thus, collaboration between those knowledgeable of both SCM and CE will be instrumental for developing ideal networks and processes that support fulfilment (see Figure 5).
Supply chain management for circular economy 


\section{IJLM \\ 32,2}

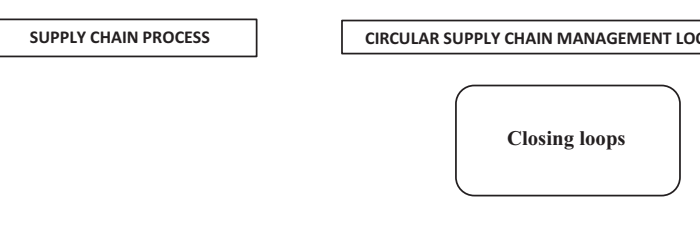

522

Figure 5.

OF process interface with circular supply chain loops and the relative activities

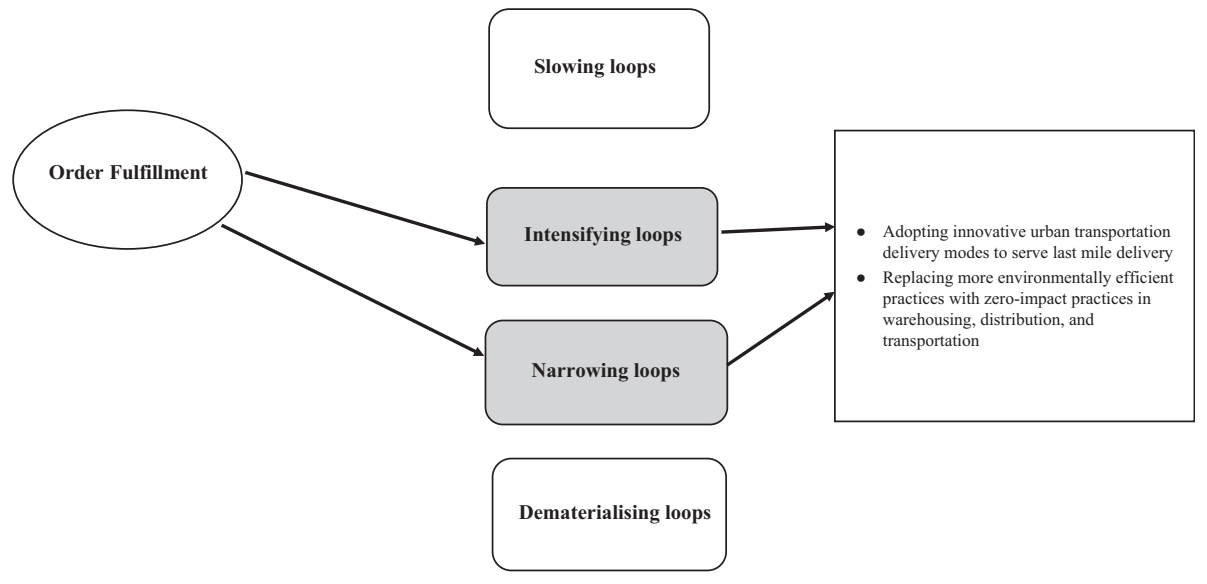

Manufacturing flow management for $C E$

Manufacturing flow management is the SCM process that includes all activities necessary to move products through manufacturing plants (Goldsby and Garcia-Dastugue, 2003). Many sustainable supply chain and operations flow strategies begin with lean and six sigma process improvement initiatives (Souza, 2012), with the assumption that leaner processes will require less energy and reduce resource consumption. In most cases, these improved processes indeed lead to better resource utilization. However, although supply chain-wide optimization is the goal, these initiatives often result in local optimization. Thus, more collaborative work is needed by SCM and CE experts to determine how to not only lean entire supply chains, but also to manage supply chain-level flows consistent with resource preservation principles. The goal, then, is not resource savings, but complete resource recapitalization.

For CE to come to fruition, the idea of accounting for and managing national material resources should be expanded (Fishman et al., 2014) and resource extraction needs to decline in favour of reutilizing existing resources (European Environmental Agency, 2014). The environmental economics perspective considers a material balance principle, implying that all material flows need to be accounted for (Kneese et al., 2015). In business, however, management attention is typically given to the flow of economic values, not necessarily physical flows or environmental values (Andersen, 2007). Flow rates, cycle times, and similar metrics are typically designed and measured from the economic perspective, and process metrics for environmental flows or natural resources (energy and raw materials) are scarce in the literature, and almost non-existent in practice. Thus, a new manufacturing flow paradigm is needed that takes these considerations into account. Although firms are creating their own metrics aimed toward monitoring and controlling manufacturing flow for $\mathrm{CE}$, collaboration between $\mathrm{CE}$ and SCM experts is needed to develop a common framework of metrics and benchmarks that transcend one-dimensional sustainability metrics in favour of balancing consideration for both economic and environmental value (see Figure 6). 


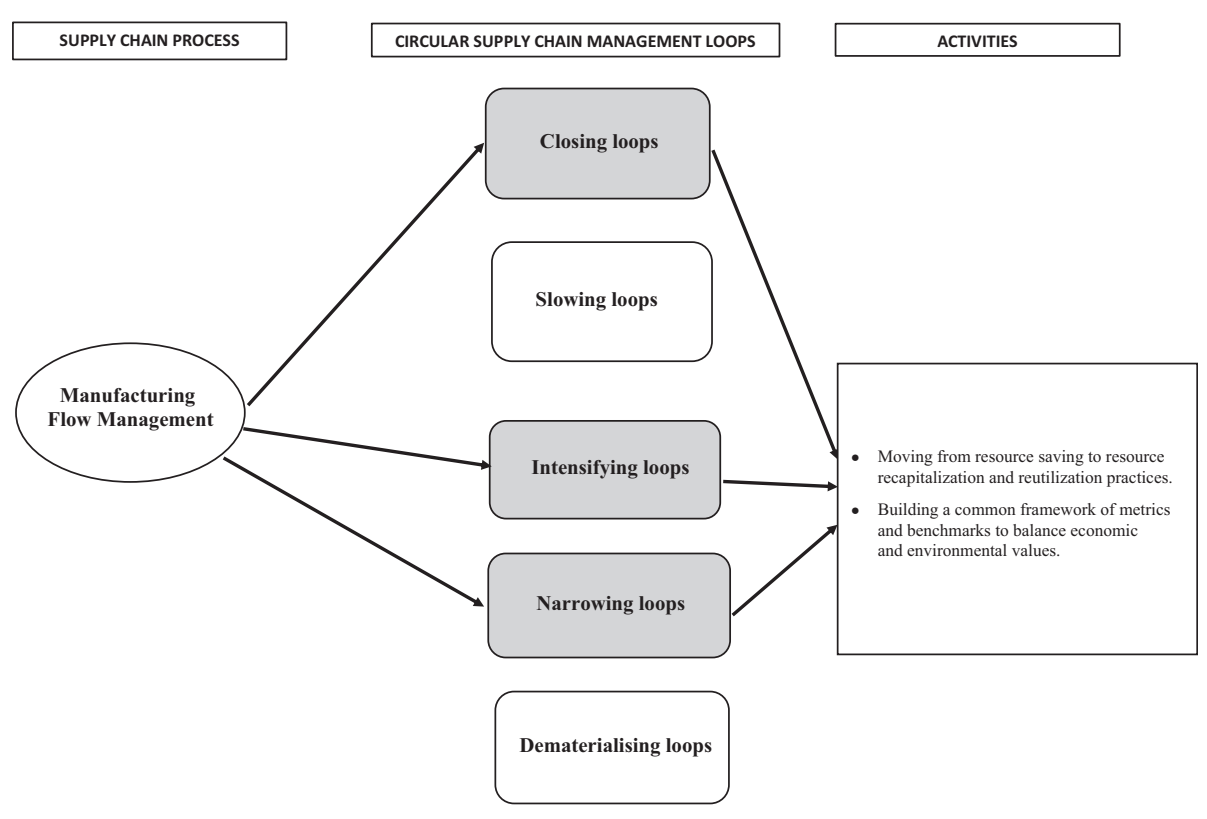

Supply chain management for circular economy

523

Product development and commercialization for $C E$

Product development and commercialization is the SCM process that provides structure for developing and bringing to market new products jointly with customers and suppliers (Rogers et al., 2004). Products need to be redesigned with a circular lifecycle in mind, requiring design for remanufacture, recycling, reuse, and other circular initiatives (Hatcher et al., 2014). This principle is tied to the value co-creation literature, where firms work with suppliers and customers during development of new product offerings.

As with manufacturing flow management (and indeed all SCM processes), new indexes and metrics need to be developed to measure performance and compliance with $\mathrm{CE}$ in terms of product development and commercialization, taking into account progress toward reduction, reuse and resource utilization (Zhijun and Nailing, 2007). Standards such as those proposed by the Cradle to Cradle Products Innovation Institute (BSI Group, 2014), Scotland's Revolve Re-use Quality Standard, or perhaps expanded ISO 9000-series standards can be used to include these considerations. Policies motivating such commonly adopted metrics will be key SCM performance indicators that can be monitored and managed during transition of product development and commercialization practices to enable CE (Preston, 2012).

Product modularity is seen as a key success factor for closed-loop supply chains (Krikke et al, 2004), and will necessarily be the same for CE. Modularity describes the ease of which product and service components can be deconstructed and recombined, and is an important consideration in design for remanufacturing, reusing and recycling (Hatcher et al, 2014). However, cellular phone and other consumer electronics manufacturers, for example, deliberately plan obsolescence in an attempt to accelerate product life-cycles and demand for new products (Choney, 2009). In turn, this discourages modular design to some extent in an effort to maximize profits. However, original equipment manufacturers and independent remanufacturers have begun to develop strategies to recover, recapture value from, and resell products that consumers discard when upgrading to new releases (Anthony, 2013; Herb Weisbaum, 2019). Product design for durability and maintainability is considered a key strategy for extending life cycles (Dalhammar, 2016). For 
IJLM 32,2

\section{4}

instance, HP's "Instant Ink" program takes steps to reuse and reuse components, saving up to $67 \%$ material consumption per printed page (Coro Strandberg, 2017). Research that examines how to motivate modular design principles in a way that supports recapturing value to a maximum extent in both primary and secondary markets is needed.

When natural resources are converted into consumable products, those resources and the resources used in production need to be recapitalized. This challenges traditional product development practices, where profit functions and market share are typically seen as the primary objective functions. Literature in the fields of industrial ecology and cleaner production has been instrumental in making advances toward resource reduction and regeneration during product development and commercialization. However, many in the supply chain, marketing and operations management community sometimes overlook these issues due to the more immediate need to obtain short- and medium-term financial performance. As such, the area of product development and commercialization is in arguably the greatest need of multi-disciplinary collaboration from scholars and practitioners in SCM, production and operations management, marketing, industrial ecology and CE. An established literature stream examines the concept of Design for $X$, where " $X$ " denotes an interchangeable variable that describes a specific design outcome Bocken et al. (2016). This method is recommended as a good practice for medical and electronic devices with a concurrent engineering approach to improve the product and its manufacturing processes during the design stage. This includes, for instance, Design for Environment (DfE), which considers the life cycle of all materials from extraction to disposal. For example, in 2009 the European Union established mandatory rules on eco-design for refrigerating appliances for all manufacturers and suppliers. Starting in 2021, that regulation will be enhanced to include requirements for repairability and recyclability, which will promote CE goals by improving the life span, maintenance, re-use, upgrade, recyclability and waste handling of appliances.

A growing body of research (Lee and Lee, 2015) indicates that Internet of Things (IoT) offers many new opportunities, brought about by improved consumer experiences, distribution and

Figure 7.

PD \&C process interface with circular supply chain loops and the relative activities

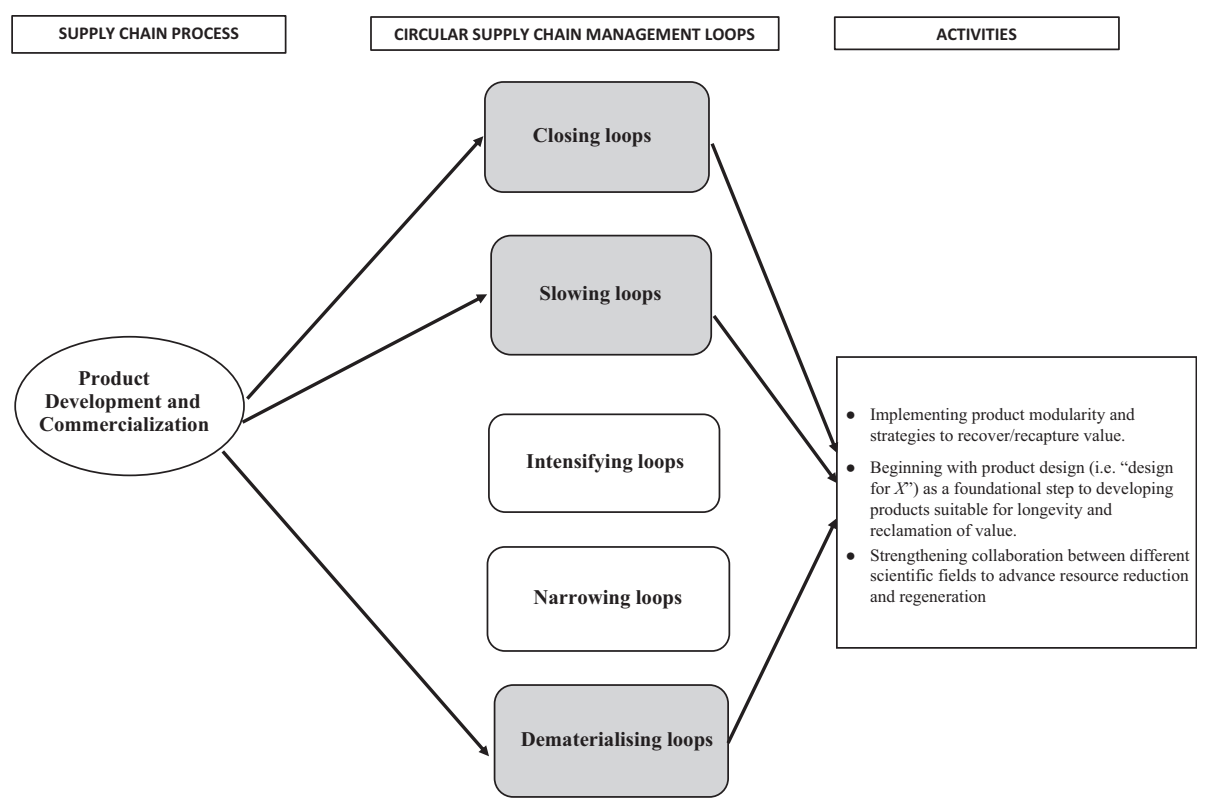


commercialization processes as well as a significant shift in the way products are utilized. To this end, businesses and scholars are exploring the different interactions between $\mathrm{CE}$ activities and intelligent technology (Stahel, 2015), which should encourage supply chain researchers to further investigate how the diffusion of new technologies and innovations are able to enable CE (see Figure 7).

\section{Returns management for CE}

Returns management is the SCM process by which activities associated with returns, reverse logistics, gate keeping, and returns avoidance are managed within the firm and across members of the supply chain (Rogers et al., 2002). Reverse flows do not necessarily travel back through the same forward-logistics channel, but typically require different treatment. Thus, service levels, fill rates and other important performance measures need to be considered for flows in both directions (Hall et al., 2013). Returns management plays an integral role in avoiding disposal and retaining resource values, which in turn supports the resource base and (to an extent) helps to retain amenity values.

Regarding changing the linear consumption model to support product take-back, business-to-business relationships will necessarily require all businesses to re-engineer their roles as suppliers and customers to support multi-directional flows. This idea has already seen attention in the literature on returns management, where internal processes are modified and new processes are put into place to support reverse flows (Rogers et al., 2012; Stock and Mulki, 2009; Mollenkopf et al., 2007).

To date, the returns management research literature provides a solid foundation for $\mathrm{CE}$ implementation in regard to outlining how to recapture resources from business customers and end-consumers. For instance, waste-to-energy technologies are being developed (Pan et al., 2015) and research is exploring how by-products created during product use can be recaptured (Linton et al., 2007). In addition, reverse logistics network development has seen a great deal of attention, and robust networks are operationalized by both brick-and-mortar and e-commerce businesses alike (Murfield et al., 2017). Recently, Bernon et al., 2018 found evidence of where reverse logistics practices were aligned with $\mathrm{CE}$ principles but had not been recognized as such by companies.

The ability to collaborate with various parties plays in the reverse chain as a crucial role as in the forward chain. In fact, what makes a forward supply chain successful is the collaboration, visibility, and trust of the various entities involved. This is also true for the reverse chain, especially because the returns management process is also heavily demand driven, as the downstream customers make the final decision about orders and returns (Morgan et al., 2016; Russo et al., 2019a, b).

However, many of these more recent advances are unfamiliar to those working on $\mathrm{CE}$ efforts, and SCM scholars are unaware of the specific emerging needs of $\mathrm{CE}$. As such, there is a need for knowledge sharing between SCM and CE scholars to develop returns management policies and practices that specifically support $\mathrm{CE}$; however, the literature disproportionately focuses on investigating how firms can mitigate the cost of product returns (Wang et al., 2017) and how consumers evaluate positively return policies (Rao et al., 2018). Indeed, CE will require different returns-management approaches that account for larger returns volumes, create scalable networks and consider additional nodes of collection and re-insertion of resources and waste at points along the supply chain that are typically not examined due to a lack of perceived value to today's economically-driven business landscape. For instance, the economic cost of recapturing small waste streams and low-volume returns is typically too high in today's economy, yet recapturing all resources will be a requirement for $\mathrm{CE}$ (see Figure 8).

Supply chain management for circular economy 
Figure 8.

RM process interface with circular supply chain loops and the relative activities

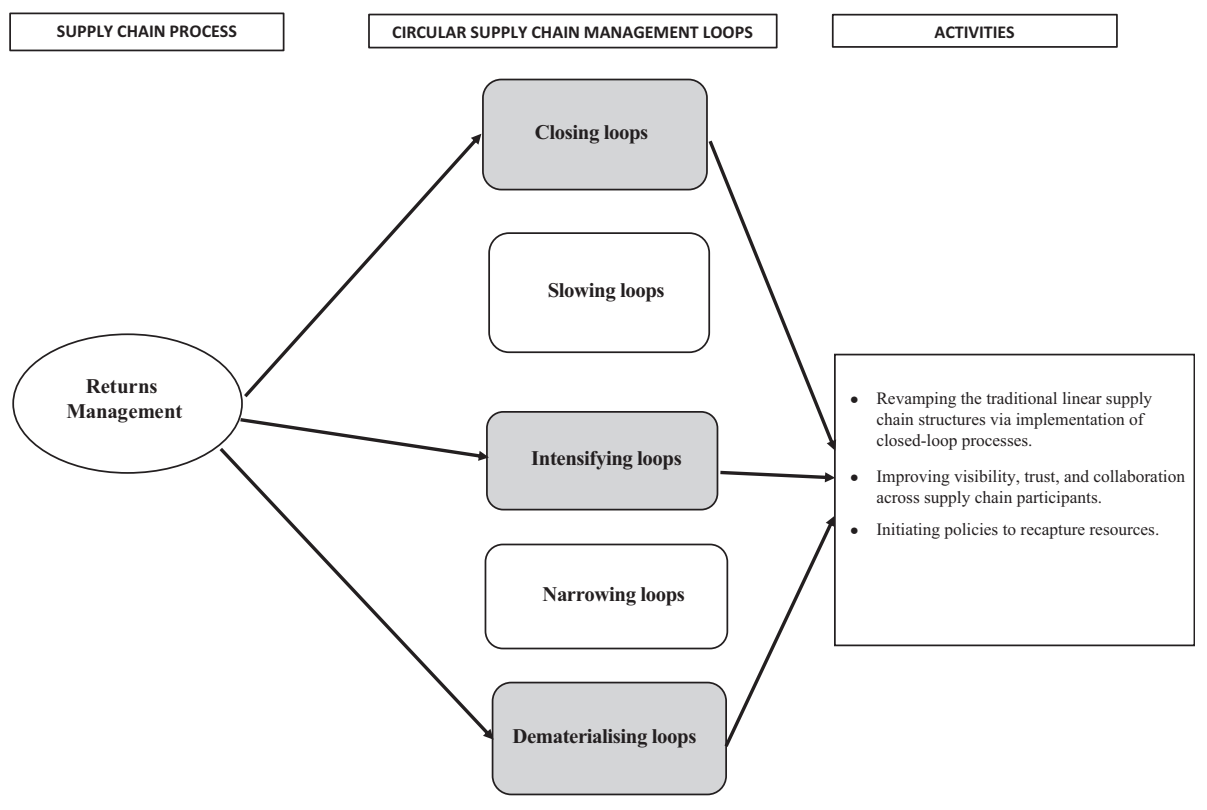

\section{Avenues for future SCM research in support of CE}

As discussed, CE for SCM focuses on closing resource loops, slowing resource loops, narrowing resources loops, dematerialising resource loops and intensifying resource loops. In detail, closing loop defines the practice to reuse the materials through recycling (Bocken et al., 2016; Geissdoerfer et al., 2018), whereas the slowing loop aims at designing durable goods and product-life extension (Leising et al., 2018). The narrowing loop concerns resource efficiency via using fewer resources per product (Bocken et al., 2016), and the dematerializing loop refers to substituting product utility with services and software solutions, with the purpose of increasing longevity. Finally, the intensifying loop motivates a more intensive product use phase that creates more efficient value (Geissdoerfer et al., 2018). We adapted this framework to explain how SCM processes interface with circular supply chain loops, as shown in Figure 9.

The multiple ways that SCM can impact CE implementation open a number of a new avenues for research. As with any investigation, research into SCM for CE must be theoretically driven. Application of general theoretical frameworks borrowed from other disciplines - such as resource-based theory, transaction cost economics or social exchange theory - can be helpful in this regard. Application of these general theoretical frames could aid researchers in defining major concepts as well as promote a better sense of the primary antecedents and outcomes of these concepts (Pellathy et al., 2018). Middle-range theory would be more useful in producing a detailed narrative of causal processes and the conditions under which supply chain processes generate CE-related outcomes (Stank et al., 2017). Middle-range theorizing, for instance, is well suited to understanding how companies should develop their approach to CE practices, the contextual factors shaping those practices, and how different approaches generate different outcomes. Given the practical nature of many of the issues involved, middle-range theorizing, which provides a nuanced understanding of why particular outcomes occur in a given 


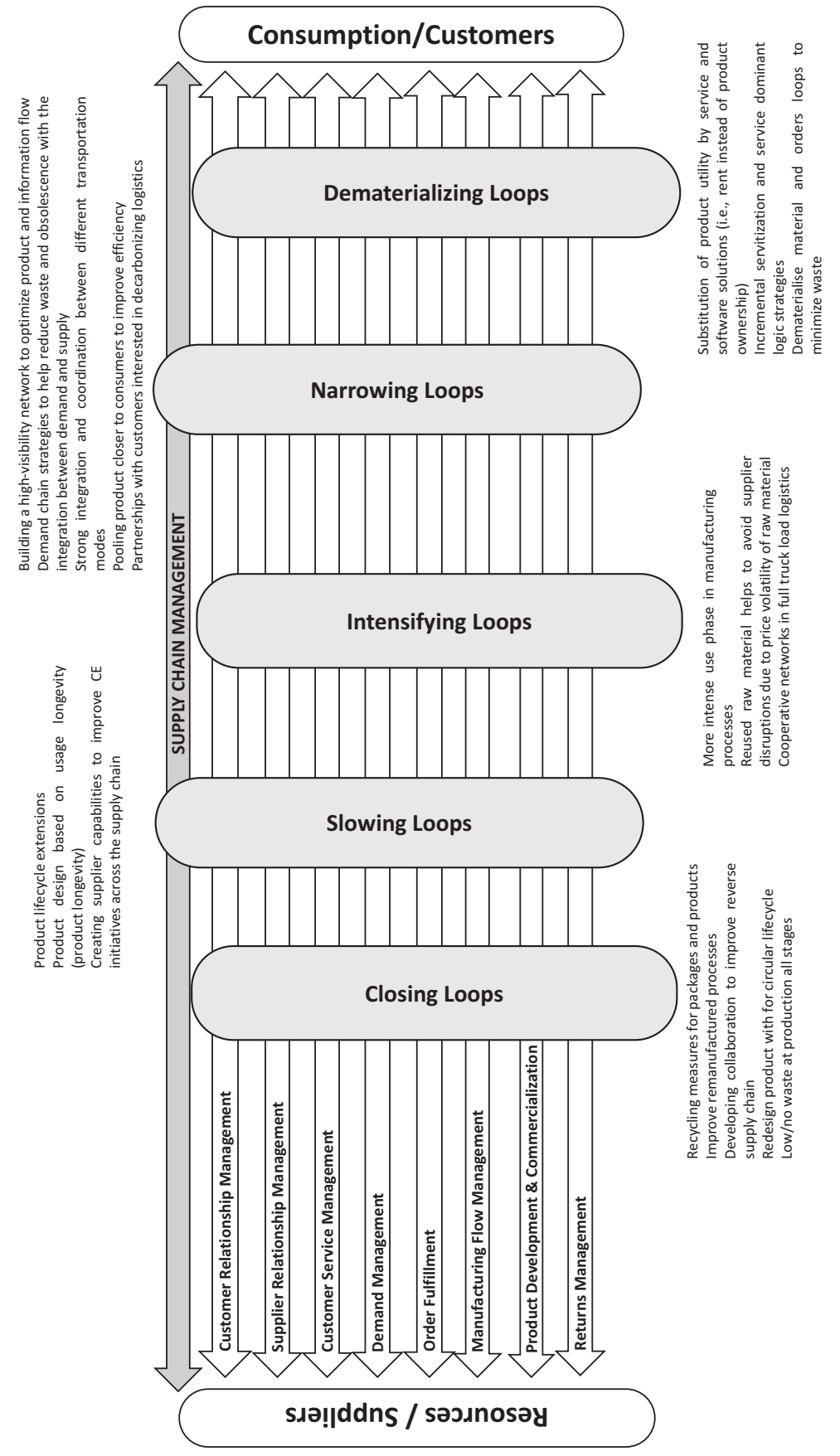

Supply chain management for circular economy

Figure 9. Circular economy and supply chain management processes 
IJLM 32,2

\section{8}

setting, would be particularly important for managers seeking to implement CE initiatives in their supply chain organizations (Christensen and Raynor, 2003). The process of middle-range theorizing has been described in detail also in the supply chain literature (Stank et al., 2017; Pellathy et al., 2018; Bastl et al., 2019). The ideas in this paper pose a number of questions that lend themselves to theorizing at both a grand and middle-range levels.

\section{Closing loops in the SC}

Within the context of SCM, closing loops focuses on increased utilization of reused/ remanufactured/recycled goods. As noted earlier, if closing loops in the supply chain is to succeed, change must start with customer perceptions and behaviours. Upstream supply chain processes must then be redesigned to accommodate customers' desired value. Thus, a number of critical questions emerge regarding the value that customers place on reused/remanufactured/recycled goods, their wiliness to accept these goods and the ways in which companies can proactively shape consumer perceptions and demand toward greater adoption of these goods. Answering these questions will require SCM researchers to engage with important work done in changing customer value perceptions (Flint et al., 2002), shopper ecosystems (Stolze et al., 2016) and demand-supply integration (Jüttner et al., 2007).

\section{Slowing loops in the SC}

Slowing loops in SCM focuses on prolonging the use of goods through the design of long life goods and product lifecycle extensions. Far too many companies pursue a myopic strategy of selling customers low quality goods with ever shorter lifespans (Rivera and Lallmahomed, 2016). Such a strategy can damage company profitability over time while training customers to view products as low quality and easily expendable (Kuppelwieser et al., 2019). Moreover, as a recent EU reported pointed out, the economic potential in shifting toward maintaining and repairing existing products is almost four times the potential in selling customers new products (EU Parliament Report, 2016). Nevertheless, companies continue to rely on outdated and environmentally unsustainable practices such as planned obsolescence without any supporting product service systems (Kessler and Brendel, 2016). Slowing loops therefore requires companies shift from a model that emphasizes shortening the replacement cycle so as to motivate new product sales to a model that provides post-sale service based on an understanding of the adequate longevity of a product.

\section{Intensifying loops in the SC}

$\mathrm{SC}$ managers have been leaders in maximizing productivity through waste reduction and the introduction of new technologies for decades. However, there are aspects of intensifying loops in the broader supply chain that managers may be less familiar with. For instance, a central focus in intensifying loops includes increasing the use of shared resources through business platforms that maximize existing capacity and build economies of scale. The key concept here might be co-opetition, which would allow supply chains within the same industry to exploit shared resources while maintaining competing offerings (Shockley and Fetter, 2015; Rai, 2016). Intensifying loops also includes greater servitization of the supply chain. One way servitization can happen is through business models that emphasize resource access over ownership (Schaefers et al., 2016). Airbnb, Uber and other stars of the sharing economy have made a big impression on social media but have yet to make a similar impact on how managers think about their supply chains. Tapping into 
existing resources that are underutilized, for instance by crowdsourcing last mile delivery (Castillo et al., 2018), can open significant opportunities to improve outcomes without the cost and environmental damage of developing new resources from scratch. Significant disruptions to the global supply chains in recent years, and especially in consideration of the global COVID-19 pandemic, have already pushed companies to conserve and intensify resource usage (Chenneveau et al., 2020). These trends could be built on from a specifically $\mathrm{CE}$ perspective. How can a focus on intensifying resources alleviate operational bottleneck stemming from perceived resource constraints? How can a focus on intensifying resources improve customer service and other performance outcomes? How can companies tap into innovations in the sharing economy to increase the servitization of their supply chains?

\section{Narrowing loops in the SC}

As with intensifying loops, narrowing loops focuses on reducing resource usage and improving efficiency in the production process. And here too, supply chain managers likely feel they have a grasp on the central issues, having grapple for years with the implementation of lean, JIT, and other efficiency boosting process improvements. However, digitalization of the supply chain - the single most disruptive factor related to narrowing loops - remains a challenge. Digitalization refers to leveraging information capturing and processing capabilities to redefine an organization's value creation process and the human-technology interactions that underlie that process (Cecere, 2017). With the emergence of a supply chain ecosystem built on integrated technologies and fuelled by digital information flows, digitalization has the potential to significantly narrow loops by giving managers unprecedented ability to respond to customer demand without maintaining excess inventory (Transvoyant, 2017). These capabilities are manifest in some responses to COVID-19, where companies are able to implement more efficient processes, reduce their transaction costs and streamline operations to accommodate social distancing (Kechichian and Mahmoud, 2020). Additive manufacturing is yet another innovation among many that are narrowing loops in the supply chain. Still managers remain unsure of how and when to implement these technologies and need research guidance on the best strategies moving forward (Gligor et al., 2019).

\section{Dematerializing loops in the SC}

Finally, and perhaps most importantly, researchers need to provide guidance on ways in which managers can focus on dematerializing loops within the supply chain. Ultimately, dematerializing loops in the $\mathrm{SC}$ is about using less to do more, making it the holy grail of $\mathrm{CE}$. Dematerialization can include digitizing processes, for instance by using communications technology to foster digital collaboration, or servitizing products, as in the case of eBooks. However, most supply chain process and products do not lend themselves to complete dematerialization. The goal for most companies, therefore, is to rethink their supply chain to ensure they are using the most effective materials in the most efficient way possible. The product packaging industry has been a leader in this regard, offering packaging solutions that are smaller, lighter and thinner but just as effective (De Koeijer et al., 2017). Walmart, a recognized leader in SCM, has supported many of these packaging innovations with waste reduction commitments (Walmart, 2016). Other examples include lightweight auto body designs that use less materials and are far more fuel efficient (Pyper, 2012) and the miniaturization of technologies (Felba, 2011). Unfortunately, dematerialization is perhaps the most under-researched of the five CE loops discussed here. However, it is in the area of dematerialization that researchers and practitioners can have the biggest impact in realizing a SC designed for CE.
Supply chain management for circular economy 
IJLM

32,2

530

\section{Concluding remarks}

$\mathrm{CE}$ represents one of the most promising avenues for addressing the ecological degradation that threatens the global environment. Central to $\mathrm{CE}$ initiatives is a reconfiguration of core supply chain processes that underlie production and consumption patterns. Yet, few studies have systematically investigated the intersection between core supply chain processes and CE. This paper provides a review of the ways in which core supply chain processes can support the successful implementation of $\mathrm{CE}$ initiatives. The article highlights areas of interest in hopes of sparking collaboration among scholars and practitioners in SCM, CE, and related fields.

Advances in $\mathrm{CE}$ will require many aspects of the supply chain to be reimagined, going beyond the current thinking in the sustainable SCM literature. SCM scholars and practitioners must embrace the notion that the world's population cannot sustain its desired level of consumption without changing the way products are sourced, produced, delivered, reclaimed, and regenerated. This article provides a framework that can ignite collaboration between $\mathrm{CE}$ and SCM experts by suggesting areas in need of cooperative study. In doing so, it proposes a new element to SCM theory by taking processes from this domain and showing how they relate to advancing CE. Indeed, work is required to promote public awareness and acceptance of CE (Russo et al., 2019a, b), and the SCM community needs to have greater awareness of CE needs and implications (Liu et al., 2018). The theorizing in this article can be used to support future inquiry into increasing understanding and dissemination of how SCM will indeed be the driving factor behind $\mathrm{CE}$.

\section{References}

Abbey, J.D., Meloy, M.G., Guide, V.D.R. and Atalay, S. (2015), "Remanufactured products in closedloop supply chains for consumer goods", Production and Operations Management, Vol. 24 No. 3, pp. 488-503.

Alstone, P., Lai, P., Mills, E. and Jacobson, A. (2014), "High life cycle efficacy explains fast energy payback for improved off-grid lighting systems", Journal of Industrial Ecology, Vol. 18 No. 5, pp. $722-733$.

Amazon Prime Now (2015), Retrieved July 20, 2019, available at: https:/primenow.amazon.com/ onboard? sourceUrl $=\% 2 \mathrm{~F}$.

Andersen, M.S. (2007), "An introductory note on the environmental economics of the circular economy”, Sustainability Science, Vol. 2 No. 1, pp. 133-140.

Anthony, P. (2013), “Cell phone buyback | e-cycle”, available at: http://www.e-cycle.com/tag/cell-phonebuyback-2/ (accessed 12 July 2019).

Barnosky, A.D., Hadly, E.A., Bascompte, J., Berlow, E.L., Brown, J.H., Fortelius, M. and Martinez, N.D. (2012), "Approaching a state shift in Earth's biosphere", Nature, Vol. 486 No. 7401, p. 52.

Bastl, M., Johnson, M. and Finne, M. (2019), “A mid-range theory of control and coordination in service triads", Journal of Supply Chain Management, Vol. 55 No. 1, pp. 21-47.

Benjamin, J. (2016), "Apple begins selling refurbished iPhones through its online store for the first time", available at: https://9to5mac.com/2016/11/08/apple-begins-selling-refurbished-iphonesthrough-its-online-store-for-the-first-time/.

Bernon, M., Tjahjono, B. and Ripanti, E.F. (2018), “Aligning retail reverse logistics practice with circular economy values: an exploratory framework", Production Planning and Control, Vol. 29 No. 6, pp. 483-497.

Blackburn, J.D., Guide, V.D.R. Jr, Souza, G.C. and Van Wassenhove, L.N. (2004), "Reverse supply chains for commercial returns", California Management Review, Vol. 46 No. 2, pp. 6-22.

Bocken, N.M., De Pauw, I., Bakker, C. and van der Grinten, B. (2016), "Product design and business model strategies for a circular economy", Journal of Industrial and Production Engineering, Vol. 33 No. 5, pp. 308-320. 
BSI Group (2014), “BS 8001 circular economy | BSI group”, Retrieved December3, 2019, available at: https://www.bsigroup.com/en-GB/standards/benefits-of-using-standards/becoming-moresustainable-with-standards/BS8001-Circular-Economy/.

Carr, A.S. and Pearson, J.N. (1999), "Strategically managed buyer-supplier relationships and performance outcomes", Journal of Operations Management, Vol. 17 No. 5, pp. 497-519.

Carter, C.R. and Rogers, D.S. (2008), "A framework of sustainable supply chain management: moving toward new theory", International Journal of Physical Distribution and Logistics Management, Vol. 38 No. 5, pp. 360-387.

Castillo, V.E., Bell, J.E., Rose, W.J. and Rodrigues, A.M. (2018), "Crowdsourcing last mile delivery: strategic implications and future research directions", Journal of Business Logistics, Vol. 39 No. 1, pp. 7-25.

Cecere, L. (2017), Driving Digital Supply Chain Transformation - A Handbook for Action, Supply Chain Insights, Philadelphia, PA.

Cerchione, R. and Esposito, E. (2016), "A systematic review of supply chain knowledge management research: state of the art and research opportunities", International Journal of Production Economics, Vol. 182, pp. 276-292.

Chenneveau, D., Eloot, Kuentz, J.F. and Lehnich, M. (2020), "Coronavirus and technology supply chains: how to restart and rebuild”, Mckinsey \& Company, Retrieved May 25, 2020, available at: https://www.mckinsey.com/business-functions/operations/our-insights/coronavirus-andtechnology-supply-chains-how-to-restart-and-rebuild.

Choney, S. (2009), "Planned obsolescence: cell phone models change", Digital Home | NBC News, Retrieved July 12, 2018, available at: http://www.nbcnews.com/id/29258026/ - .UolmU8Rq-So\#. W0chmLh9g2w.

Christensen, C.M. and Raynor, M.E. (2003), "Why hard-nosed executives should care about management theory", Harvard Business Review, Vol. 81 No. 9, pp. 66-75.

Christopher, M. and Ryals, L.J. (2014), "The supply chain becomes the demand chain”, Journal of Business Logistics, Vol. 35 No. 1, pp. 29-35.

Cole, D., Mahapatra, S. and Webster, S. (2017), “A comparison of buyback and trade-in policies to acquire used products for remanufacturing", Journal of Business Logistics, Vol. 38 No. 3, pp. 217-232.

Coro Strandberg (2017), "The circular economy in action: HP leading the way", available at: https:// sustainablebrands.com/read/product-service-design-innovation/the-circular-economy-in-actionhp-leading-the-way.

Croxton, K.L. (2003), "The order fulfillment process", The International Journal of Logistics Management, Vol. 14 No. 1, pp. 19-32.

Dalhammar, C. (2016), "Industry attitudes towards ecodesign standards for improved resource efficiency”, Journal of Cleaner Production, Vol. 123, pp. 155-166.

de Angelis, R., Howard, M. and Miemczyk, J. (2018), "Supply chain management and the circular economy: towards the circular supply chain”, Production Planning and Control, Vol. 29 No. 6, pp. $425-437$.

de Koeijer, B., Wever, R. and Henseler, J. (2017), "Realizing product-packaging combinations in circular systems: shaping the research agenda", Packaging Technology and Science, Vol. 30 No. 8, pp. 443-460.

Edvardsson, B., Tronvoll, B. and Gruber, T. (2011), "Expanding understanding of service exchange and value co-creation: a social construction approach", Journal of the Academy of Marketing Science, Vol. 39 No. 2, pp. 327-339.

Ellen MacArthur Foundation (2015), "Growth within: a circular economy vision for a competitive Europe", available at: https://www.ellenmacarthurfoundation.org/assets/downloads/ publications/EllenMacArthurFoundation_Growth-Within_July15.pdf.
Supply chain management for circular economy 
IJLM 32,2

\section{2}

Esper, T.L. and Peinkofer, S.T. (2017), "Consumer-based supply chain management performance research: a structured literature review”, Transportation Journal, Vol. 56 No. 4, pp. 395-428.

European Commission (2020), "A new circular economy action plan", For a cleaner and more competitive Europe Retrieved April 20, 2020, available at: https://eur-lex.europa.eu/legalcontent/EN/TXT/HTML/?uri=CELEX:52020DC0098\&from $=$ EN.

European Environmental Agency (2014), "EEA signals 2014 well-being and the environment European environment agency", Retrieved Nov 19, 2019, available at: https://www.eea.europa. eu/publications/signals-2014.

European Parliament (2016), "A longer lifetime for products: benefits for consumers and companies", available at: http://www.europarl.europa.eu/RegData/etudes/STUD/2016/579000/IPOL_ STU(2016)579000_EN.pdf.

Farooque, M., Zhang, A., Thurer, M., Qu, T. and Huisingh, D. (2019), "Circular supply chain management: a definition and structured literature review", Journal of Cleaner Production, Vol. 228, pp. 882-900.

Felba, J. (2011), "Thermally conductive adhesives in electronics", in Advanced Adhesives in Electronics, Woodhead Publishing, pp. 15-52.

Fishman, T., Schandl, H., Tanikawa, H., Walker, P. and Krausmann, F. (2014), "Accounting for the material stock of nations", Journal of Industrial Ecology, Vol. 18 No. 3, pp. 407-420.

Flint, D.J., Woodruff, R.B. and Gardial, S.F. (2002), "Exploring the phenomenon of customers' desired value change in a business-to-business context”, Journal of Marketing, Vol. 66 No. 4, pp. 102-117.

Frankel, R., Bolumole, Y.A., Eltantawy, R.A., Paulraj, A. and Gundlach, G.T. (2008), "The domain and scope of SCM's foundational disciplines-insights and issues to advance research", Journal of Business Logistics, Vol. 29 No. 1, pp. 1-30.

Geissdoerfer, M., Savaget, P., Bocken, N.M.P. and Hultink, E.J. (2017), "The circular economy - a new sustainability paradigm?”, Journal of Cleaner Production, Vol. 143, pp. 757-768.

Geissdoerfer, M., Morioka, S.N., de Carvalho, M.M. and Evans, S. (2018), "Business models and supply chains for the circular economy", Journal of Cleaner Production, Vol. 190, pp. 712-721.

General Motors (2016), "GM and Lyft to shape the future of mobility”, Retrieved Dec 1, 2019, available at: http://media.gm.com/media/us/en/gm/home.detail.html/content/Pages/news/us/en/2016/Jan/ 0104-lyft.html.

Ghisellini, P., Cialani, C. and Ulgiati, S. (2016), "A review on circular economy: the expected transition to a balanced interplay of environmental and economic systems", Journal of Cleaner Production, Vol. 114, pp. 11-32.

Gligor, D., Bozkurt, S., Russo, I. and Omar, A. (2019), "A look into the past and future: theories within supply chain management, marketing and management", Supply Chain Management: An International Journal, Vol. 24 No. 1, pp. 170-186.

Goldsby, T. and Garcia-Dastugue, S. (2003), "The manufacturing flow management process", The International Journal of Logistics Management, Vol. 14 No. 2, pp. 33-52.

Govindan, K. and Hasanagic, M. (2018), "A systematic review on drivers, barriers, and practices towards circular economy: a supply chain perspective", International Journal of Production Research, Vol. 56 Nos 1-2, pp. 278-311.

Govindan, K. and Soleimani, H. (2017), "A review of reverse logistics and closed-loop supply chains: a Journal of Cleaner Production focus", Journal of Cleaner Production, Vol. 142, pp. 371-384.

Guide, V.D.R. Jr and Van Wassenhove, L.N. (2009), "The evolution of closed-loop supply chain research”, Operations Research, Vol. 57 No. 1, pp. 10-18.

H\&M (2019), "Recycling”, Retrieved July 13, 2019, available at: https://hmgroup.com/sustainability/ Planet/recycling.html.

Habibi, M.K., Battaïa, O., Cung, V.D. and Dolgui, A. (2017), "Collection-disassembly problem in reverse supply chain”, International Journal of Production Economics, Vol. 183, pp. 334-344. 
Hall, D.J., Huscroft, J.R., Hazen, B.T. and Hanna, J.B. (2013), "Reverse logistics goals, metrics, and challenges: perspectives from industry", International Journal of Physical Distribution and Logistics Management, Vol. 43 No. 9, pp. 768-785.

Hardin, G. (1968), "The tragedy of the commons", Science, Vol. 162 No. 3859, pp. 1243-1248.

Hatcher, G.D., Ijomah, W.L. and Windmill, J.F.C. (2014), "A network model to assist "design for remanufacture" integration into the design process", Journal of Cleaner Production, Vol. 64, pp. 244-253.

Hazen, B.T., Cegielski, C. and Hanna, J.B. (2011), "Diffusion of green supply chain management: examining perceived quality of green reverse logistics", The International Journal of Logistics Management, Vol. 22 No. 3, pp. 373-389.

Hazen, B.T., Overstreet, R.E., Jones-Farmer, L.A. and Field, H.S. (2012), "The role of ambiguity tolerance in consumer perception of remanufactured products", International Journal of Production Economics, Vol. 135 No. 2, pp. 781-790.

Hazen, B., Boone, C., Wang, Y. and Khor, K. (2017), "Perceived quality of remanufactured products: construct and measure development", Journal of Cleaner Production, Vol. 142, pp. 716-726.

Heikkurinen, P. (2018), "Degrowth by means of technology? A treatise for an ethos of releasement", Journal of Cleaner Production, Vol. 197, pp. 1654-1665.

Herb Weisbaum (2019), "How to recycle, resell and buy used electronics", available at: https://www. nbcnews.com/better/lifestyle/how-recycle-resell-buy-used-electronics-ncna996956.

IKEA (2016), "IWAY standard", available at: https://www.ikea.com/ms/it_CH/pdf/reports-downloads/ ikea-code-of-conduct-the-iway-standard-it.pdf.

IPBES (2018), "The IPBES regional assessment report on biodiversity and ecosystem services for Europe and Central Asia", in Rounsevell, M., Fischer, M., Torre-Marin Rando, A. and Mader, A. (Eds), Secretariat of the Intergovernmental Science-Policy Platform on Biodiversity and Ecosystem Services, Bonn, p. 892.

Jaakkola, E. (2020), "Designing conceptual articles: four approaches”, AMS Review, pp. 1-9.

Jüttner, U., Christopher, M. and Baker, S. (2007), "Demand chain management-integrating marketing and supply chain management", Industrial Marketing Management, Vol. 36 No. 3, pp. 377-392.

Kazancoglu, Y., Kazancoglu, I. and Sagnak, M. (2018), “A new holistic conceptual framework for green supply chain management performance assessment based on circular economy", Journal of Cleaner Production, Vol. 195, pp. 1282-1299.

Kechichian, E. and Mahmoud, N. (2020), "The circular economy can support COVID-19 Response and build resilience", World Bank, Retrieved May 20th, 2020, available at: https://blogs.worldbank. org/psd/circular-economy-can-support-covid-19-response-and-build-resilience.

Kessler, T. and Brendel, J. (2016), "Planned obsolescence and product-service systems: linking two contradictory business models", Journal of Competence-Based Strategic Management, Vol. 8, pp. 29-53.

Kirchoff, J.F., Omar, A. and Fugate, B.S. (2016), "A behavioral theory of sustainable supply chain management decision making in non-exemplar firms", Journal of Supply Chain Management, Vol. 52 No. 1, pp. 41-65.

Kneese, A.V., Ayres, R.U. and d'Arge, R.C. (2015), Economics and the Environment, Routledge.

Krikke, H., le Blanc, I. and van de Velde, S. (2004), "Product modularity and the design of closed-loop supply chains”, California Management Review, Vol. 46 No. 2, pp. 23-39.

Kuppelwieser, V.G., Klaus, P., Manthiou, A. and Boujena, O. (2019), "Consumer responses to planned obsolescence”, Journal of Retailing and Consumer Services, Vol. 47, pp. 157-165.

Lambert, D.M. (2014), Supply Chain Management: Processes, Partnerships, Performance, 4th ed., Supply Chain Management Institute, Sarasota, FL.
Supply chain

management for circular economy 
IJLM 32,2

Lambert, D.M. (2019), "Rediscovering relevance", International Journal of Logistics Management, Vol. 30 No. 2, pp. 382-394.

Lambert, D. and Cooper, M. (2000), "Issues in supply chain management", Industrial Marketing Management, Vol. 29 No. 1, pp. 65-83.

Lambert, D.M. and Enz, M.G. (2015), "We must find the courage to change”, Journal of Business Logistics, Vol. 36 No. 1, pp. 9-17.

Lee, I. and Lee, K. (2015), "The Internet of Things (IoT): applications, investments, and challenges for enterprises”, Business Horizons, Vol. 58 No. 4, pp. 431-440.

Leising, E., Quist, J. and Bocken, N. (2018), "Circular economy in the building sector: three cases and a collaboration tool", Journal of Cleaner Production, Vol. 176, pp. 976-989.

Liang, D. (2011), "Four major bottlenecks to the development of remanufacturing industry to be broken", available at: http://ibd.shangbao.net.cn/a/56485.html.

Linton, J.D., Klassen, R. and Jayaraman, V. (2007), "Sustainable supply chains: an introduction", Journal of Operations Management, Vol. 25 No. 6, pp. 1075-1082.

Liu, J., Feng, Y., Zhu, Q. and Sarkis, J. (2018), "Green supply chain management and the circular economy: reviewing theory for advancement of both fields", International Journal of Physical Distribution and Logistics Management, Vol. 48 No. 8, pp. 794-817.

Lukka, K. and Vinnari, E. (2014), "Domain theory and method theory in management accounting research", Accounting, Auditing and Accountability Journal, Vol. 27 No. 8, pp. 1308-1338.

Martínez-Jurado, P.J. and Moyano-Fuentes, J. (2014), "Lean management, supply chain management and sustainability: a literature review", Journal of Cleaner Production, Vol. 85, pp. 134-150.

Mathews, J.A. and Tan, H. (2011), "Progress toward a circular economy in China: the drivers (and inhibitors) of eco-industrial initiative", Journal of Industrial Ecology, Vol. 15 No. 3, pp. 435-457.

McKinnon, A.C. (2013), "Starry-eyed: journal rankings and the future of logistics research", International Journal of Physical Distribution and Logistics Management, Vol. 43 No. 1, pp. 6-17.

McKinnon, A., Cullinane, S., Whiteing, A. and Browne, M. (2010), Green Logistics: Improving the Environmental Sustainability of Logistics, Vol. 1, Kogan Page, Londres, Philadelfia and Nova Delhi, p. 372.

Mentzer, J.T. (2008), "Rigor versus relevance: why would we choose only one?", Journal of Supply Chain Management, Vol. 44 No. 2, p. 72.

Min, S., Zacharia, Z.G. and Smith, C.D. (2019), "Defining supply chain management: in the past, present, and future", Journal of Business Logistics, Vol. 40 No. 1, pp. 44-55.

Mollenkopf, D., Russo, I. and Frankel, R. (2007), "The returns management process in supply chain strategy", International Journal of Physical Distribution and Logistics Management, Vol. 37 No. 7, pp. 568-592.

Mollenkopf, D., et al. (2010), “Green, lean, and global supply chains”, International Journal of Physical Distribution and Logistics Management, Vol. 40 Nos 1/2, pp. 14-41.

Mollenkopf, D., Stolze, H., Tate, W.L. and Ueltschy, M. (2010), “Green, lean, and global supply chains”, International Journal of Physical Distribution and Logistics Management, Vol. 40 Nos 1/2, pp. 14-41.

Monczka, R.M., Petersen, K.J., Handfield, R.B. and Ragatz, G.L. (1998), "Success factors in strategic supplier alliances: the buying company perspective”, Decision Sciences, Vol. 29 No. 3, pp. 553-577.

Morgan, T.R., Richey, R.G. Jr and Autry, C.W. (2016), "Developing a reverse logistics competency: the influence of collaboration and information technology", International Journal of Physical Distribution and Logistics Management, Vol. 46 No. 3, pp. 293-315.

Murfield, M., Boone, C.A., Rutner, P. and Thomas, R. (2017), "Investigating logistics service quality in Omni-channel retailing", International Journal of Physical Distribution and Logistics Management, Vol. 47 No. 4, pp. 263-296. 
Murphy, P.R., Poist, R.F. and Braunschweig, C.D. (1996), "Green logistics: comparative views of environmental progressives, moderates, and conservatives", Journal of Business Logistics, Vol. 17 No. 1, pp. 191-211.

Neely, A. (2009), "Exploring the financial consequences of the servitization of manufacturing", Operations Management Research, Vol. 1 No. 2, pp. 103-118.

Ng, I., Parry, G., Smith, L., Maull, R. and Briscoe, G. (2012), "Transitioning from a goods-dominant to a service-dominant logic: visualising the value proposition of Rolls-Royce", Journal of Service Management, Vol. 23 No. 3, pp. 416-439.

Ostrom, E., Burger, J., Field, C.B., Norgaard, R.B. and Policansky, D. (1999), "Revisiting the commons: local lessons, global challenges", Science, Vol. 284 No. 5412, pp. 278-282.

Pan, S.Y., Du, M.A., Huang, I., Te, Liu, I.H., Chang, E.E. and Chiang, P.C. (2015), "Strategies on implementation of waste-to-energy (WTE) supply chain for circular economy system: a review", Journal of Cleaner Production, Vol. 108, pp. 409-421.

Pearce, D.W. and Turner, K.R. (1990), Economics of Natural Resources and the Environment, JHU Press.

Pellathy, D.A., In, J., Mollenkopf, D.A. and Stank, T.P. (2018), "Middle-range theorizing on logistics customer service", International Journal of Physical Distribution and Logistics Management, Vol. 48 No. 1, pp. 2-18.

Petljak, K., Zulauf, K., Štulec, I., Seuring, S. and Wagner, R. (2018), “Green supply chain management in food retailing: survey-based evidence in Croatia", Supply Chain Management: An International Journal, Vol. 23 No. 1, pp. 1-15.

Preston, F. (2012), “A global redesign? Shaping the circular economy”, Chatham House,Retrieved July 12, 2019, available at: https://www.chathamhouse.org/publications/papers/view/182376.

Prieto-Sandoval, V., Jaca, C. and Ormazabal, M. (2018), "Towards a consensus on the circular economy", Journal of Cleaner Production, Vol. 179, pp. 605-615.

Pyper, J. (2012), “To boost gas mileage, automakers explore lighter cars”, available at: https:/www. scientificamerican.com/article/to-boost-gas-mileage-automakers-explore-lighter-cars/.

Rai, R.K. (2016), "A co-opetition-based approach to value creation in interfirm alliances: construction of a measure and examination of its psychometric properties", Journal of Management, Vol. 42 No. 6, pp. 1663-1699.

Rao, P. and Holt, D. (2005), "Do green supply chains lead to competitiveness and economic performance?", International Journal of Operations and Production Management, Vol. 25 No. 9, pp. 898-916.

Rao, S., Lee, K.B., Connelly, B. and Iyengar, D. (2018), "Return time leniency in online retail: a signaling theory perspective on buying outcomes", Decision Sciences, Vol. 49 No. 2, pp. 275-305.

Reinders, M.J., Onwezen, M.C. and Meeusen, M.J.G. (2017), "Can bio-based attributes upgrade a brand? How partial and full use of bio-based materials affects the purchase intention of brands", Journal of Cleaner Production, Vol. 162, pp. 1169-1179.

Rivera, J.L. and Lallmahomed, A. (2016), "Environmental implications of planned obsolescence and product lifetime: a literature review", International Journal of Sustainable Engineering, Vol. 9 No. 2, pp. 119-129.

Rogers, D.S., Lambert, D., Croxton, K.L. and Garcia-Dastugue, S. (2002), "The returns management process", International Journal of Logistics Management, Vol. 13 No. 2, pp. 1-18.

Rogers, D.S., Lambert, D. and Knemeyer, A.M. (2004), "The product development and commercialization process", International Journal of Logistics Management, Vol. 15 No. 1, pp. 43-56.

Rogers, D.S., Melamed, B. and Lembke, R.S. (2012), "Modeling and analysis of reverse logistics", Journal of Business Logistics, Vol. 33 No. 2, pp. 107-117.

Russo, I., Confente, I., Scarpi, D. and Hazen, B. (2019a), "From trash to treasure: the impact of consumer perception of bio-waste products in closed-loop supply chains", Journal of Cleaner Production, Vol. 218, pp. 966-974.
Supply chain management for circular economy 
IJLM 32,2

Russo, I., Confente, I., Gligor, D. and Cobelli, N. (2019b), "A roadmap for applying qualitative comparative analysis in supply chain research: the reverse supply chain case", International Journal of Physical Distribution and Logistics Management, Vol. 49 No. 1, pp. 99-120.

Sarkis, J., Zhu, Q. and Lai, K.H. (2011), “An organizational theoretic review of green supply chain management literature", International Journal of Production Economics, Vol. 130 No. 1, pp. 1-15.

Sashi, Cerchione, R., Singh, R., Centobelli, P. and Shabani, A. (2018), "Food cold chain management: from a structured literature review to a conceptual framework and research agenda", International Journal of Logistics Management, Vol. 29 No. 3, pp. 792-821.

Schaefers, T., Lawson, S.J. and Kukar-Kinney, M. (2016), "How the burdens of ownership promote consumer usage of access-based services”, Marketing Letters, Vol. 27 No. 3, pp. 569-577.

Shockley, J. and Fetter, G. (2015), "Distribution co-opetition and multi-level inventory management performance: an industry analysis and simulation", Journal of Purchasing and Supply Management, Vol. 21 No. 1, pp. 51-63.

Souza, G.C. (2012), Sustainable Operations and Closed-Loop Supply Chains, Business Expert Press.

Srivastava, S.K. (2007), "Green supply-chain management: a state-of-the-art literature review", International Journal of Management Reviews, Vol. 9 No. 1, pp. 53-80.

Stahel, W.R. (2015), "Circular economy”, Nature, pp. 6-9.

Stank, T.P., Pellathy, D.A., In, J., Mollenkopf, D.A. and Bell, J.E. (2017), "New frontiers in logistics research: theorizing at the middle range”, Journal of Business Logistics, Vol. 38 No. 1, pp. 6-17.

Steffen, W., et al. (2015), "Planetary boundaries: guiding human development on a changing planet", Science, Vol. 347 No. 6223, p. 1259855.

Stindt, D., Sahamie, R., Nuss, C. and Tuma, A. (2016), "How transdisciplinarity can help to improve operations research on sustainable supply chains-a transdisciplinary modeling framework", Journal of Business Logistics, Vol. 37 No. 2, pp. 113-131.

Stock, J.R. and Mulki, J.P. (2009), "Product returns processing: an examination of practices of manufacturers, wholesalers/distributors, and retailers", Journal of Business Logistics, Vol. 30 No. 1, pp. 33-62.

Stolze, H.J., Mollenkopf, D.A. and Flint, D.J. (2016), "What is the right supply chain for your shopper? Exploring the shopper service ecosystem", Journal of Business Logistics, Vol. 37 No. 2, pp. 185-197.

Su, B., Heshmati, A., Geng, Y. and Yu, X. (2013), "A review of the circular economy in China: moving from rhetoric to implementation", Journal of Cleaner Production, Vol. 42, pp. 215-227.

Thierry, M., Salomon, M., Van Nunen, J. and Wassenhove, L. (1995), "Strategic issues in product recovery management", Long Range Planning, Vol. 28 No. 3, p. 120.

Tjahjono, B. and Ripanti, E. (2019), "Circular economy-what does it mean for remanufacturing operations?”, available at: https://www.linkedin.com/pulse/circular-economy-what-does-meanremanufacturing-operations-høegh/.

Transvoyant (2017), "Supply chain visibility is dead: continuously predicting behavior is driving far more value", available at: https://scg-lm.s3.amazonaws.com/pdfs/transvoyant_wp_ supplychainvisibilityisdead_110617b.pdf (accessed 8 November 2019).

Walmart (2016), "Walmart 2016 global responsibility report", available at: https://corporate.walmart. com/2016grr/enhancing-sustainability/moving-toward-a-zero-waste-future.

Wang, Y. and Hazen, B.T. (2016), "Consumer product knowledge and intention to purchase remanufactured products", International Journal of Production Economics, Vol. 181, pp. 460-469.

Wang, J.-J., Chen, H., Rogers, D.S., Ellram, L.M. and Grawe, S.J. (2017), "A bibliometric analysis of reverse logistics research (1992-2015) and opportunities for future research", International Journal of Physical Distribution and Logistics Management, Vol. 47 No. 8, pp. 666-687. 
Whetten, D.A. (1989), "What constitutes a theoretical contribution?", Academy of Management Review, Vol. 14 No. 4, pp. 490-495.

Whetten, D.A. (2009), "An examination of the interface between context and theory applied to the study of Chinese organizations", Management and Organization Review, Vol. 5 No. 1, pp. 29-56.

World Economic Forum (2014), Towards the Circular Economy: Accelerating the Scale-Up across Global Supply Chains, World Economic Forum, (January), pp. 1-64.

World Economic Forum (2019), "IKEA is now selling and leasing refurbished furniture", available at: https://www.weforum.org/agenda/2019/02/ikea-is-now-selling-and-leasing-refurbished-furniturein-hopes-of-creating-a-circular-business/.

Ying, J. and Li-jun, Z. (2012), "Study on green supply chain management based on circular economy", Physics Procedia, Vol. 25, pp. 1682-1688.

Zeng, H., Chen, X., Xiao, X. and Zhou, Z. (2017), "Institutional pressures, sustainable supply chain management, and circular economy capability: empirical evidence from Chinese eco-industrial park firms", Journal of Cleaner Production, Vol. 155, pp. 54-65.

Zheng, L. and Zhang, J. (2010), "Research on green logistics system based on circular economy", Asian Social Science, Vol. 6 No. 11, p. 116.

Zhijun, F. and Nailing, Y. (2007), "Putting a circular economy into practice in China", Sustainability Science, Vol. 2 No. 1, pp. 95-101.

Zhu, Q., Geng, Y. and Lai, K. (2011), "Environmental supply chain cooperation and its effect on the circular economy practice-performance relationship among Chinese manufacturers", Journal of Industrial Ecology, Vol. 15 No. 3, pp. 405-419.

\section{Corresponding author}

Benjamin T. Hazen can be contacted at: hazenscm@gmail.com
Supply chain management for circular economy

$-$ 